\title{
TURKISH DELIGHT FOR SOME, COLD TURKEY FOR OTHERS?: \\ THE EFFECTS OF THE EU-TURKEY CUSTOMS UNION
}

\author{
ANTONIS ADAM \\ THOMAS MOUTOS \\ CESIFO WORKING PAPER NO. 1550 \\ CATEgOry 7: TRAde Policy \\ SEPTEMBER 2005 \\ An electronic version of the paper may be downloaded \\ - from the SSRN website: \\ www.SSRN.com \\ - from the CESifo website: www.CESifo-group.de
}




\title{
TURKISH DELIGHT FOR SOME, COLD TURKEY FOR OTHERS?: THE EFFECTS OF THE EU-TURKEY CUSTOMS UNION
}

\begin{abstract}
Following Turkey's application for EU membership in 1987, a Customs Union (CU) between Turkey and the EU, mainly covering trade in manufacturing goods and processed agricultural products, came into effect in 1995. In addition to a large agricultural sector, Turkey also specializes in the production and exportation of relatively low-price, low-quality varieties of manufactured products. We use a theoretical framework in order to demonstrate that these features of the Turkish economy imply asymmetric changes in the trade volumes of the incumbent countries of the EU as a result of the EU-Turkey CU. By examining disaggregated trade data we find that the technologically sophisticated EU countries (e.g., mainly the Northern European countries) are also least similar to Turkey in terms of their export structure, whereas the degree of export similarity between the less technologically sophisticated EU members and Turkey is high. Our econometric results indicate that, in contrast to the "Northern" group's exports to other EU15 countries (which have remained intact), the Southern countries's exports to the other EU15 countries have declined as a result of the EU-Turkey CU. Moreover, the extra penetration of the Turkish market by EU countries has not been more favourable to the Southern group. These findings also imply that technologically sophisticated countries may see no significant further benefits from Turkey's full accession to the EU (whereas the migration and political influence related costs for these countries may be large).
\end{abstract}

JEL Code: F13, F15.

Keywords: European Union, Turkey, customs union, exports, gravity, differentiated products.

Antonis Adam

Thomas Moutos

Athens University of Economics and Business Athens University of Economics and Business

Department of International and European Economic Studies

Patission 76

Athens 10434

Greece

Department of International and

European Economic Studies

aadam@aueb.gr

Patission 76
Athens 10434
Greece
tmoutos@aueb.gr

We wish to thank Panos Hatzipanayotou and George Zanias for helpful comments and suggestions. 


\section{Introduction}

The starting point of Turkey's involvement with the EU goes back to 1959, shortly after the creation of the European Economic Community (EEC), when Turkey applied to become an associate member. The result of this was the Ankara Agreement, which is considered as the basis of EU-Turkish relations. The Ankara Agreement aimed to strengthen economic and trade relations between the EEC and Turkey and contribute to Turkey's development through the eventual establishment of a customs union. Signed on September 12, 1963, and put into effect on December 1, 1964, the Agreement pledged to consider Turkey for full membership if and when it could prove its capacity to undertake the responsibilities set out in the Agreement. Much like the Athens Agreement signed with Greece in 1961, the Ankara Agreement, in principle, sought to prepare Turkey for full membership through economic integration.

The culmination of 30 years of commercial association (which it had many ups and downs - see the following section for more details) was solidified with the EU-Turkish customs union (CU) agreement in March 1995, which came into effect in January 1996. In Helsinki, in December 1999, the European Council decided to grant Turkey (which had applied for full EU membership in 1987) the official status of an accession candidate. The European Council considered at that point that Turkey had the basic features of a democratic system but displayed serious shortcomings in terms of human rights and the protection of minorities. With these issues in mind, in December 2002 the Copenhagen European Council concluded that the European Council of December 2004 should decide on the basis of a report and a recommendation from the Commission whether Turkey fulfilled the Copenhagen political criteria (i.e., that a candidate should be "a stable democracy, respecting human rights, the rule of law, and the protection of minorities") and whether the EU would open accession negotiations with Turkey. In October 2004 the European Commission concluded that Turkey fulfils the Copenhagen criteria, and at the December 2004 Brussels European Council it was decided that accession negotiations will open with Turkey in October 2005. 
The purpose of this paper is to evaluate the (possibly differential) effects of the EUTurkey CU agreement of 1995, and on the basis of this to gauge the future likely impact of the Turkish accession to the EU. The existing literature on the effects of the $\mathrm{CU}$ agreement has focused mainly on the likely impact of the $\mathrm{CU}$ agreement on the Turkish economy. Mercenier and Yeldan (1997) conclude, on the basis of a calibrated intertemporal general equilibrium model, that the impact of the $\mathrm{CU}$ on the Turkish economy will be negative due to the terms of trade deterioration which will result from the larger drop in the tariff rates which Turkey had to implement (given that the existing EU tariffs on Turkish exports were already low) ${ }^{1}$. Mercenier and Yeldan calculate also the likely effects for Turkey resulting from full EU membership and find them to be positive since that would involve the elimination of non-tariff barriers (NTBs) which would have significant pro-competitive effects on the Turkish economy. On the opposite side, Harrison, Rutherford and Tarr (1997) concluded that CU agreement would result in rather significant gains for the Turkish economy, to the order of $1 \%$ to $1.5 \%$ of Turkish GDP, mainly due to the fact that the trade diversion involved for Turkey would be rather small since the EU common external tariff which it would have to adopt stood only at about $2 \%$ for non-agricultural goods.

To our knowledge the only study that has tried to estimate the effects for both the EU countries and Turkey is Lejour and De Mooij (2004). On the basis of a computable general equilibrium (CGE) model for the world economy, they calculate the effects of (i) Turkey's accession to the internal European Market, (ii) institutional reforms in Turkey triggered by EU-membership; and (iii) migration in response to the free movement of workers. They find that the effects of Turkey's accession to the single market are substantial and positive for Turkey, small but positive for the 10 countries that have recently acceded to the EU and negligible for the EU(15). Moreover, the sectoral effects for the EU countries are not expected to be large. It is predicted that the agricultural, textile and wearing apparel sectors will suffer a small decline in the EU countries (although this decline will be mostly concentrated in the Southern countries of EU15 and in the 10 new members), whereas the Chemicals, Metals and Transport Equipment sectors are predicted to marginally expand in the EU countries.

\footnotetext{
${ }^{1}$ In a similar vein Erzan and Filiztekin (1997) questioned the ability of the small- and medium-scale Turkish enterprises to withstand the competitive pressure (at least in the short-run) that the CU would bring about.
} 
In the present study we argue that the salient features of both the EU(15) countries and Turkey are conducive to making the effects of the EU-Turkey CU asymmetric. In order to support our argument we present two models: the first one assumes that international trade involves the exchange of homogeneous goods, whereas the second model assumes that trade involves the exchange of vertically differentiated products. The first model generates the prediction that the more similar is the export structure of an incumbent country with the joining country, the larger will be the crowding-out of this country's exports to the other incumbent countries as a result of the CU expansion ${ }^{2}$. The second model generates the prediction that the more contiguous an incumbent country is to the joining country in terms of technological sophistication, the larger will be the crowding-out of this country's exports to the other incumbent countries as a result of the CU expansion.

In the empirical section of the paper we investigate whether the EU-Turkey CU produced the type of asymmetric effects on the EU15 countries's exports identified above. To this purpose we use the gravity model of international trade, which has during the last decade established itself as the workhorse for many empirical investigations in international economics. Even though many authors have used the gravity framework in order to analyse various issues relating to regional trade agreements, the possibility of asymmetric effects of $\mathrm{CU}$ expansion on the exports of incumbent countries to other CU members has -to our knowledge- not been studied before(see Greenaway and Milner, 2002, for a survey). Our strategy is to, first, use the gravity model in order to infer the "normal" amount of Turkish manufacturing exports to the EU15, which would obtain during the 1996-2002 period, in the absence of the CU agreement. We then calculate the difference between actual Turkish exports and our estimation of "normal" Turkish exports, and identify this as our measure of the extra Turkish exports to the EU15 caused by the CU agreement. The influence of this measure on the exports of each EU15 country to the rest of the EU15 countries is then assessed by estimating a gravity model under two assumptions: first that the effect of the CU agreement is symmetric across the EU15 countries, and, second, that the effect

\footnotetext{
${ }^{2}$ The effects of the CU expansion on the welfare of each country (traditionally measured as the sum of changes in consumer surplus, producer surplus and government revenue) are also discussed in this section.
} 
is asymmetric. We find that the CU agreement has adversely affected the exports only of those EU countries whose export structure is most similar to Turkey's and have the lowest level of technological sophistication (we term this group South), whereas for the rest of the EU countries (the North) the effect has been both economically negligible and statistically insignificant. In addition, we find that the increase in the Northern group's exports to Turkey (above what the gravity model would deem "normal"), was higher than the corresponding variable for the South. Both of these findings suggest, much as in the case of a single country whose factors of production are differentially affected by trade liberalization, that the inter-country effects of the EU-Turkey CU have been asymmetric and in accordance with our theoretical framework.

\section{From Ankara to Brussels ${ }^{3}$}

The Ankara Agreement in 1963 specified that the process of economic integration between Turkey and the EEC, which would prepare Turkey for full membership to the Community, should involve three stages: the preliminary stage, the transition stage and the final stage. During the preliminary stage, which was to be from 1964 to 1973, the EEC would give some direct financial aid to Turkey and establish preferential trade conditions with Turkey. The transition stage was supposed to last for 22 years, during which the Community and Turkey would eliminate all tariffs and trade barriers in order to establish a customs union between Turkey and the Community. At the final stage, if sufficient progress were to be observed, the Community would examine the possibility of Turkey's accession to the Community as a full member.

The preliminary stage was completed in five years without any problems and Turkey took the necessary steps to initiate the second stage of the Assosiation Agreement. During, the transitional stage, which was aimed at setting the timetable towards the establisment of a CU between the parties by 1995, the Additional Protocol, was signed in 1970, but came into effect in January 1973. The Additional Protocol covered Turkey's and the EEC's trade and financial commitments to each other. After the Additional Protocol was signed, the EEC abolished tariffs and equivalent taxes (as of

\footnotetext{
${ }^{3}$ This section borrows heavily from Togan (1995), Togan (1997), Hartrel and Laird (1999), European Commission (2002), Flam (2003), Hughes (2004), and Ulgen and Zahariadis (2004).
} 
September 1971) on industrial imports from Turkey, with the exception of certain sensitive products such as machine woven carpets, cotton yarn and cotton textiles. The EEC also removed all quantitative restrictions on industrial imports from Turkey with the exception of restriction on imports of cocoons and raw silk. However, it did continue to apply quotas and minimum import prices which were within the framework of the Common Agricultural Policy. With these actions, the EEC had fulfilled most of its obligations during the transition period. However, its non-tariff barriers against some of the goods in which Turkey (presumably) had comparative advantage (e.g., textiles, iron and steel, raisins, fresh fruits and vegetables) has been one of the main problems between Turkey and the EU.

During the first four years of the transitional period (1973-1976), the implementation of the Additional Protocol went ahead as planned. However, after 1976, the process of implementing the Additional Protocol came to a virtual standstill since Turkey was unable to reduce the tariffs as planned. In January 1977, Turkey postponed the first step of her scheduled tariff alignment with the Common Customs Tariff. One year later she also postponed the third round of tariff reductions (Togan, 1995). During the period 1976-1987 the Turkey-EEC relations were strained. The first disappointment emerged after the first oil crisis, as rising unemployment in Europe limited labour movements from Turkey to the member states, demonstrating the Community's inability to comply with the provisions of the Additional Protocol concerning the free mobility of labour. Another major problem sprang from the extension of concessions by the EEC to many LDC's under the General System of Preferences,more importantly, under the Mediterranean Policy which considerably eroded the preferences granted to Turkish agriculture and industry. In addition, the economic (oil) crisis in 1973 and the 1987 Single European Act were the major concerns of the Community that made the Community very cautious in eliminating tariffs and other trade barriers with Turkey, especially in textile and agricultural products.

On 14 April 1987 Turkey formally applied for full EEC membership. Many observers considered this to be a premature application. However, the Community did not want to alienate Turkey. Hence, the Commission prepared its official "Opinion" and issued it in December 1989. In February 1990, the EC member states concluded on the basis of the 'Opinion' of Commission that it would be inappropriate for the Community, 
which was in a state of flux, to become involved in new accession negotiations. The completion in 1995 of the $\mathrm{CU}$, in accordance with the provision of the Agreement was considered by the Commision to be of prime importance for increased interdependence and integration between Turkey and the Community. At a meeting of the Association Council at ministerial level on 9 November 1992 both sides agreed to restart the implementation of the provision laid down in the Association Agreement. Until the end of the 1995, Turkey fulfilled all her tariff reductions which was mentioned in twelve and twenty two years lists in the Additonal Protocol. On March 1995, it was agreed at the Association Council meeting in Brussels, that Turkey would join the European Customs Union.

The CU came into force in January 1996. As a member of the CU, Turkey, eliminated all custom duties, quantitative restrictions, and all charges which have equivalent effect to quantitative restrictions for industrial products and processed components of agricultural products in its trade with the EU and adopted the common external tariff against third country imports. ${ }^{4}$ However, the CU has developed in to a more comprehensive concept than the framework defined by the Ankara Agreement and the Additional Protocol. This is a unique, and highly complex, agreement since it involves a customs union between an existing regional trading block and an independent country. The CU between Turkey and the EU goes far beyond a basic custom union with free international trade and common external tariffs and has given new impetus to the liberalizarion process in Turkey. Apart from the liberalisation of tariffs and adoption by Turkey of the EU's common external tariff for industrial products and the industrial components of processed agricultural products, the agreement also embraces a number of integration elements; these include the adoption of the Community's commercial policy towards third countries including textile quotas, the adoption of the free trade agreements with all the EU's preferential partners including EFTA, Central and Eastern European and Mediterranean countries; co-operation on the harmonisation of agricultural policy, mutual minimisation of restriction on trade in services,

\footnotetext{
${ }^{4}$ As a consequence of the CU, Turkey's weighted tarif rates on imports of industrial products originating from the EU15 and EFTA countries have fallen from $5.9 \%$ to $0 \%$ and from $10.8 \%$ to $6 \%$ for similar goods originating from third countries. With the implementation of the Uruguay Round reductions, Turkey's average rates for third countries will be lowered to $3.5 \%$. The implication of this is that as far as tariff barriers are concerned, the relative preference given to EU goods has not increased.
} 
harmonisation of Turkey's legislation to that of the EU in the area of competition policy, state aids, anti-dumping, intellectual and industrial property rights, puplic procurement and technical barriers to trade.

The scope of the CU, however, excludes Turkey from some of the crucial aspects of the common market: the common agricultural policy, including the free circulation of agricultural products and the free movement of labour and capital. The 1995 agreement also allows for the continuation of contingent protection (anti-dumping and countervailing duties) and safeguards - which is in marked contrast to the Europe Agreements where trade defence measures are eliminated. Furthermore, Turkey did not receive anything resembling the financial assistance granted to the Cental and Eastern European Countries (CEECs), whereas the EU retains significant leeway for the continuation of various technical barriers to trade.

In Table 1 we present some data relating to the evolution of Turkey's international trade in manufacturing goods. As it is apparent from the table, while there has been an immediate surge in the share of Turkish imports originating from the EU15 countries after the signing of the CU agreement, for both exports and imports there has been no noticeable difference in the share of trade (exports plus imports) that Turkey is conducting with the EU15 between 1995 and 2003; the share of Turkish exports destined for the EU15 countries has increased slightly, whereas the share of Turkish imports originating from the EU15 has decreased. A likely explanation for this (somehow paradoxical) trend in the Turkish trade with the EU15 is the increased participation of the formerly centrally planned economies in both Europe and Asia in the world trading system. Nevertheless, even by looking at these raw data one can observe the trade diversion caused by the EU-Turkey CU by noting that the share of Turkish total trade (imports plus exports) conducted with the EU15 fell by less than two percentage points between 1995 and 2003, whereas the corresponding decline in the share of Turkish trade with the United States and Japan were seven percentage points. 
MANUFACTURING TRADE

\begin{tabular}{|c|c|c|c|c|c|c|c|c|}
\hline & \multicolumn{4}{|c|}{ Shares of Turkish Imports from } & \multicolumn{4}{|c|}{ Shares of Turkish Exports to } \\
\hline & 1989 & 1995 & 1996 & 2003 & 1989 & 1995 & 1996 & 2003 \\
\hline Austria & $1,37 \%$ & $1,00 \%$ & $1,53 \%$ & $1,40 \%$ & $1,00 \%$ & $1,02 \%$ & $1,11 \%$ & $0,94 \%$ \\
\hline Belgium-Luxembourg & $3,66 \%$ & $2,78 \%$ & $2,89 \%$ & $2,92 \%$ & $2,38 \%$ & $2,04 \%$ & $2,01 \%$ & $1,88 \%$ \\
\hline Denmark & $0,33 \%$ & $0,62 \%$ & $0,43 \%$ & $0,53 \%$ & $0,69 \%$ & $0,64 \%$ & $0,66 \%$ & $1,00 \%$ \\
\hline Finland & $0,85 \%$ & $0,80 \%$ & $0,65 \%$ & $0,79 \%$ & $0,27 \%$ & $0,17 \%$ & $0,18 \%$ & $0,45 \%$ \\
\hline France & $5,58 \%$ & $6,80 \%$ & $7,60 \%$ & $7,02 \%$ & $5,32 \%$ & $4,69 \%$ & $4,53 \%$ & $6,07 \%$ \\
\hline Germany & $19,59 \%$ & $17,83 \%$ & $21,31 \%$ & $15,77 \%$ & $20,22 \%$ & $23,73 \%$ & $23,12 \%$ & $16,00 \%$ \\
\hline Greece & $0,69 \%$ & $0,43 \%$ & $0,50 \%$ & $0,49 \%$ & $0,99 \%$ & $0,91 \%$ & $1,00 \%$ & $1,88 \%$ \\
\hline Irelan & $0,17 \%$ & $0,67 \%$ & $0,41 \%$ & $0,85 \%$ & $0,20 \%$ & $0,24 \%$ & $0,28 \%$ & $0,59 \%$ \\
\hline Italy & $9,43 \%$ & $11,05 \%$ & $12,09 \%$ & $9,13 \%$ & $8,95 \%$ & $6,51 \%$ & $5,99 \%$ & $6,61 \%$ \\
\hline $\mathrm{N}$ & $3,07 \%$ & $2,80 \%$ & $3,14 \%$ & $2,41 \%$ & $3,53 \%$ & $3,37 \%$ & $3,19 \%$ & $3,17 \%$ \\
\hline Portc & $0,08 \%$ & $0,23 \%$ & $0,23 \%$ & $0,26 \%$ & $0,09 \%$ & $0,26 \%$ & $0,26 \%$ & $0,68 \%$ \\
\hline Spair & $2,09 \%$ & $2,06 \%$ & $2,92 \%$ & $3,39 \%$ & $0,85 \%$ & $1,49 \%$ & $1,49 \%$ & $3,77 \%$ \\
\hline Sweden & $1,41 \%$ & $1,75 \%$ & $1,80 \%$ & $1,29 \%$ & $0,71 \%$ & $0,47 \%$ & $0,53 \%$ & $1,00 \%$ \\
\hline United K & $5,94 \%$ & $5,98 \%$ & $6,73 \%$ & $5,53 \%$ & $5,99 \%$ & $5,37 \%$ & $5,59 \%$ & $8,04 \%$ \\
\hline EU15 & $54,26 \%$ & $54,79 \%$ & $62,22 \%$ & $51,78 \%$ & $51,21 \%$ & $50,91 \%$ & $49,93 \%$ & $52,08 \%$ \\
\hline$\overline{\text { CEEC }}$ & $1,65 \%$ & $0,91 \%$ & $0,75 \%$ & $2,79 \%$ & $0,83 \%$ & $2,76 \%$ & $2,13 \%$ & $2,66 \%$ \\
\hline$\overline{\text { United States }}$ & $11,45 \%$ & $10,45 \%$ & $\overline{77,66 \%}$ & "4,19\% & $\overline{6,77 \%}$ & 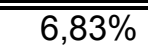 & 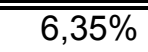 & 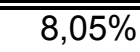 \\
\hline Japan & $4,75 \%$ & $4,89 \%$ & $4,02 \%$ & $3,28 \%$ & $1,63 \%$ & $0,63 \%$ & $0,57 \%$ & $0,24 \%$ \\
\hline Russian (Feder & $0,00 \%$ & $4,28 \%$ & $2,45 \%$ & $6,26 \%$ & $0,00 \%$ & $6,33 \%$ & $6,90 \%$ & $2,61 \%$ \\
\hline China & $0,30 \%$ & $1,81 \%$ & $1,54 \%$ & $4,27 \%$ & $0,50 \%$ & $0,21 \%$ & $0,24 \%$ & $0,96 \%$ \\
\hline OECD & $78,17 \%$ & $77,62 \%$ & $81,47 \%$ & $70,29 \%$ & $63,05 \%$ & $63,29 \%$ & $61,31 \%$ & $64,61 \%$ \\
\hline $\begin{array}{l}\text { Total non-OECD } \\
\end{array}$ & $21,83 \%$ & $21,38 \%$ & $17,64 \%$ & $28,10 \%$ & $36,92 \%$ & $34,61 \%$ & $36,56 \%$ & $30,85 \%$ \\
\hline Total World & $100,00 \%$ & $100,00 \%$ & $100,00 \%$ & $100,00 \%$ & $100,00 \%$ & $100,00 \%$ & $100,00 \%$ & $\overline{100,00 \%}$ \\
\hline
\end{tabular}

Source: OECD STAN Bilateral Trade

\section{Table 1: Turkish Foreign Trade}

The completion in 1995 of the CU, in accordance with the provision of the Agreement was considered by the Commision to be of prime importance for the increased integration between the EU and Turkey. Twelve years later than its application for EU membership, Turkey was officially recognised as an EU candidate at the Helsinki summit in December 1999, and in December 2002 the European Council announced that if it deems that Turkey sufficiently fulfils the Copenhagen political criteria it would open negotiations without delay. In October 2004 the European Commission concluded that Turkey fulfils the Copenhagen criteria, and at the December 2004 Brussels European Council it was decided that accession negotiations will open with Turkey in October 2005. In the meantime, the Commission's objective of "extending and deepening" the Customs Union (CU) was endorsed by EU Member States at the December 2002 Copenhagen Council. In order to advance the CU, Turkey and the EU are pushing ahead to deepen it into new areas such as services and public procurement. The Council has agreed on negotiating guidelines on the liberalisation of services and 
public procurement. Several rounds of negotiations have so far taken place, whereas in other areas, such as the requirement to align with the Community's preferential customs regimes, the EU has been encouraging Turkey to make further advances.

\section{Theoretical Framework}

The differential effects on the EU(15) countries of the EU-Turkey CU can arise either when trade involves the exchange of homogeneous goods, or when trade involves the exchange of vertically-differentiated products. Since the logic behind the differential impact differs in the two cases, we briefly present the underlying mechanisms of each case in the rest of this section. In order to focus on the issues which we want to highlight we consider for both cases a partial equilibrium framework of an existing customs union model involving four countries (or regions): the North $(\mathrm{N})$ and the South (S) of the EU(15), Turkey (T) and the rest of the world (R). We start our analysis by assuming the existence of a CU between North and South. We assume that there are no technical, regulatory or other cost-increasing trade barriers within the $\mathrm{CU}$, but that there is a common external tariff (CET) which it is applied on imports from either $\mathrm{T}$ or $\mathrm{R}$. We assume away the existence of (differential) transport costs between the four countries and of any other trade barriers, except the per-unit CET, $t$.

\subsection{Homogeneous Goods}

We assume the existence of a homogeneous good, $\mathrm{X}$, which is produced in both the North and South of the EU(15) and it is imported from both Turkey and the rest of the world. We start our analysis by considering the case that the North is a net importer of $\mathrm{X}$, whereas the South exports (along with $\mathrm{T}$ and $\mathrm{R}$ ) this good to N. In Figure 1, we depict the import-demand curve of $\mathrm{N}$ (the difference between domestic demand and supply) as $M_{N}$, whereas the the export supply curves (the difference between domestic supply and demand) of $\mathrm{S}, \mathrm{T}$, and $\mathrm{R}$ are depicted as $E_{S}, E_{T}$, and $E_{R}$ (respectively). The fact that the export supply elasticities of $\mathrm{S}$ and $\mathrm{T}$ are finite implies that the source of imports for this good will be both by the customs union partner and the outside world see Panagariya (2000) for a similar assumption involving the formation of a CU by two countries. 
Due to the existence of a customs union between $\mathrm{N}$ and $\mathrm{S}$, initially $\mathrm{N}$ imposes a perunit tariff at rate $\mathrm{t}$ on imports from both $\mathrm{T}$ and $\mathrm{R}$ only. This implies that the relevant export supply curves for $\mathrm{T}$ and $\mathrm{R}$ are depicted by $E_{T}^{t}$ and $E_{R}^{t}$, respectively ${ }^{5}$. The price paid by consumers in both $\mathrm{N}$ and $\mathrm{S}$ will be equal to $P_{C}^{t}$, and N's total imports will be equal to $\mathrm{OF}$, with quantity $\mathrm{OB}$ sourced from $\mathrm{S}$, quantity $\mathrm{BC}$ sourced from Turkey, and quantity CF sourced from the rest of the world. Following the expansion of the CU to include Turkey, T's export-supply curve shifts downwards (by the amount of the tariff) to $E_{T}$. We assume that the common external tariff remains unchanged after $\mathrm{T}$ becomes part of the CU. Since, by construction, $N$ continues to import from $\mathrm{R}$ as well after the $\mathrm{CU}$ expansion, the (consumer's) price within the CU remains unaltered at $P_{C}^{t}$. In this case N's aggregate volume of imports does not expand. Nevertheless, quantity CD is diverted away from the more efficient $\mathrm{R}$ to the less efficient $\mathrm{T}$, and quantity $\mathrm{AB}$ is directed away from the less efficient $\mathrm{S}$ to the more efficient $\mathrm{T}$. Accordingly, T's exports expand to $\mathrm{AD}$, to the detriment of both S's and R's exports to $\mathrm{N}$.

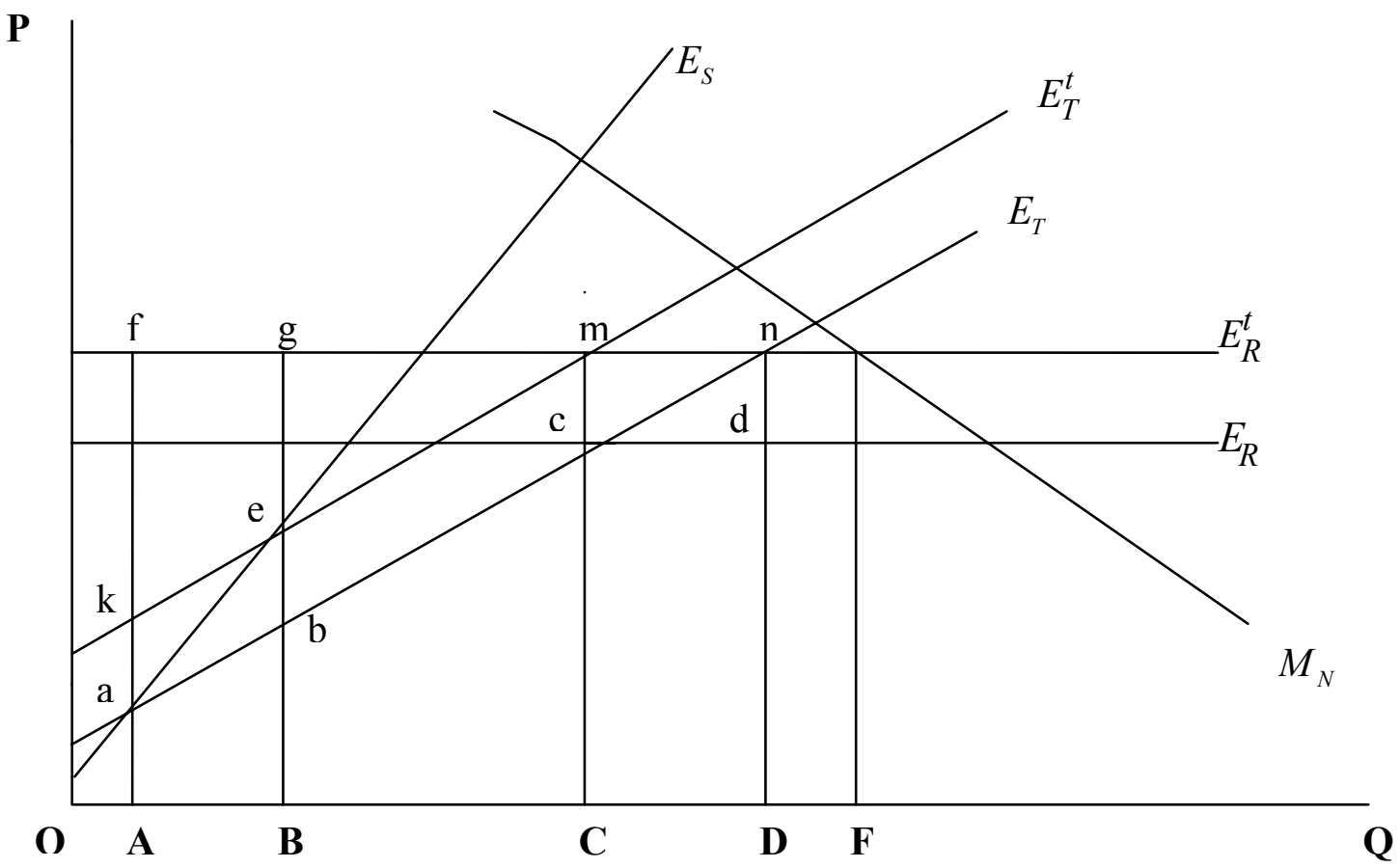

Figure 1: CU expansion with homogeneous goods

An important caveat is in order here. As far as the welfare effects of the CU expansion are concerned, we note that in this particular case, and assuming that full employment

\footnotetext{
${ }^{5}$ The horizontal axis depicts the price paid by the buyer of the good.
} 
prevails in all countries and that no other distortions are in place, there would be a loss of tariff revenue (equal to the area $c m n d$ ) for $\mathrm{N}$ and a loss of producer's surplus (equal to afge) for S. The gain to T's producers is the sum of areas afgb and cmn. The net effect on the expanded CU's welfare is ambiguous, since it depends positively on the size of area $a e b$ and negatively on the size of area $c n d$. We thus observe that both $\mathrm{N}$ and $\mathrm{S}$ lose in this case, and this obviously would also be the case if $\mathrm{S}$ had been an importer of good $\mathrm{X}$ and $\mathrm{N}$ an exporter of this good (in which case $\mathrm{S}$ would lose tariff revenue and $\mathrm{N}$ would lose producer's surplus). For goods which either $\mathrm{N}$ and/or $\mathrm{S}$ export to $\mathrm{T}$, there will be a rise in producer surplus for both countries. Thus, the welfare effects of the $\mathrm{CU}$ expansion appear symmetric for $\mathrm{N}$ and $\mathrm{S}$ even though the effects on trade are asymmetric. However, the presence of high levels of unemployment for many EU countries implies that the preceding welfare analysis is incomplete. This is because it assumes that, for example, an increase in a country's exports (and production) has no effect on aggregate employment, with the expanding sector's increase in employment coming at the expense of reduced employment in other sectors. We not only believe that this is a far-fetched assumption for most EU countries, but we are also confident that this is not the framework used by political, business or trade union leaders when thinking about the effects of trade policy. ${ }^{6} \mathrm{We}$ conclude that for both normative and pragmatic reasons the traditional focus on welfare effects which do not take into account of employment effects is misplaced, and that our focus on trade volume asymmetries is a sensible first step towards the identification of an important component of the welfare asymmetries of CU expansion in distorted economies.

Although Figure 1 is highly specific, we can still use it to draw some more general conclusions. First, we note that had $\mathrm{S}$ been an importer of good $\mathrm{X}$ and $\mathrm{N}$ an exporter of this good, it would have been N's exports to $\mathrm{S}$ that would have been displaced by the expansion of the $\mathrm{CU}$ to include $\mathrm{T}$. Second, for goods in which $\mathrm{N}$ and/or $\mathrm{S}$ are net exporters to $\mathrm{T}$, the expansion of the $\mathrm{CU}$ to include $\mathrm{T}$ will generate an increase in their exports to $\mathrm{T}$ (at the expense of R's exports), and thus cause an increase in the producer's surplus for these countries. To the extent that the increase in S's and N's

\footnotetext{
${ }^{6}$ The assumption of the absence of any distortions implies that countries can increase their welfare by taxing their exports, thus harming their trade partners. It is interesting that neither GATT nor the WTO prohibit a country from taxing its exports (which they should do since it creates negative externalities for the importing countries), although countries have found it worthwhile to bound their import tariffs.
} 
exports to Turkey is of similar value to the decline of their exports to each other, the $\mathrm{CU}$ expansion would not have any significant asymmetric effects on $\mathrm{N}$ and $\mathrm{S}$ as far as the volume of exports is concerned.

The possibility of asymmetric effects can arise if, to pick an extreme example, for the goods (call this group of goods, $\mathrm{X}$ ) in which $\mathrm{S}$ is an exporter, $\mathrm{T}$ is also an exporter (i.e., its revealed comparative advantage is in the same group of goods) whereas for the goods (call this group $\mathrm{Z}$ ) in which $\mathrm{N}$ is an exporter, $\mathrm{T}$ is an importer. In this case, the expansion of the $\mathrm{CU}$ to include $\mathrm{T}$ would largely imply that the increase of T's exports to $\mathrm{N}$ would be at the expense of S's exports to N, whereas N's exports to $\mathrm{S}$ would not be affected ${ }^{7}$. To put the issue bluntly, if the South is an exporter of agricultural goods, then its exports to North would be reduced as a result of the CU expansion to include a country which, by assumption, is mainly an exporter of agricultural goods, whereas the North's exports of manufacturing goods to the South will not be curtailed as the new entrant does not have comparative advantage in the production of these goods. We thus expect that to the extent that there are differences in the degree of export similarity between Turkey and the countries of EU (15), this would be an important factor which could explain the (possible) presence of asymmetric effects on the volume of exports across the fifteen EU countries.

\subsection{Vertically Differentiated Products}

We now assume that the four countries trade in a vertically differentiated product ${ }^{8}$. We start our analysis by assuming that within each country the vertically differentiated product, Y, is produced under perfectly competitive conditions by identical firms. (This assumption is not necessary for our analysis, but it greatly simplifies it; we discuss later the case of infra-marginal firms.) This good is differentiated according to quality, which is measured by an index $\mathrm{Q}$ in the range $[1, \infty]$. We assume that there is perfect information regarding the quality index. We further assume that production costs in all countries depend on quality and that each unit of a given quality is

\footnotetext{
${ }^{7}$ The welfare consequences of the CU expansion would also be asymmetric for the incumbent CU members in this case, but it is not clear that they would be worse for S than the N. In any case, the possible presence of other distortions (e.g., unemployment) makes the proper calculation of welfare effects beyond the scope of the present paper.

${ }^{8}$ This section relies heavily on Adam and Moutos (2004).
} 
produced at a constant cost (which differs across countries). We capture the above assumptions by writing the production function for North as

$Y_{N}(Q)=\frac{L_{N}}{\gamma_{N} Q^{\varepsilon_{N}}}, \quad \gamma_{N}>0, \varepsilon_{N}>1$,

where $Y_{N}(Q)$ denotes the number of units of quality Q produced in North, $L_{N}$ stands for the (effective) units of labor used in the production process, and $\gamma_{N}$ and $\varepsilon_{N}$ are parameters. Our assumption that $\varepsilon_{N}>1$ implies that although costs per unit in terms of quantity are constant, increases in quality are associated with more than equiproportional increases in unit costs. This assumption is motivated by the fact that increases in quality - for a given state of technological capability - require the employment of an increasing number of workers. These workers must be allocated not only to the production of a higher number of features attached to each good (e.g. electric windows, air bags, ABS, security devices, etc. in the case of automobiles) that directly absorb labor, but also to the development and refinement of these features as well. We assume that these endeavors are subject to diminishing returns (see also, Flam and Helpman (1987)).

Equation (1) implies that the average cost at which each unit of quality $\mathrm{Q}$ will be produced by Northern producers is

$$
A C_{N}(Q)=w_{N} \gamma_{N} Q^{\varepsilon_{N}}
$$

where $w_{N}$ is the Northern wage rate. We now assume that the North has absolute advantage in the production of every quality level of the differentiated good over the South, and that its comparative advantage (CA) lies in the production of high-quality varieties of the differentiated good. These assumptions are reflected in the following production function for South,

$Y_{S}(Q)=\frac{L_{S}}{\gamma_{S} Q^{\varepsilon_{S}}}, \quad \gamma_{S}>\gamma_{N}, \quad \varepsilon_{S}>\varepsilon_{N}$

According to equation (3) the average cost at which each unit of quality $\mathrm{Q}$ will be produced by Southern producers will be

$$
A C_{S}=w_{S} \gamma_{S} Q^{\varepsilon_{S}}
$$

where $w_{S}$ is the Southern wage rate. Under these conditions it is obvious that if the wage rates (per effective unit of labour) were equal in the two countries, Southern 
producers would not be able to produce any varieties at a lower cost (price) than their Northern counterparts. For this reason, we assume that wages in the South are sufficiently lower than Northern wages, i.e. that $w_{N}>w_{S}$. This assumption guarantees that Southern producers will be able to produce at least some low-quality varieties (those ones in which the country has CA) at a lower cost than Northern producers.

With respect to the rest of the world, we assume that $\mathrm{R}$ represents the most technologically sophisticated country in the world, whereas $\mathrm{T}$ is less technologically sophisticated than South. This stark assumption is made as a way of capturing the different levels of technological sophistication between $\mathrm{R}$ and $\mathrm{T}$, by placing them on the opposite sites of technological sophistication relative to the North and South (the evidence presented later in the paper is supportive of this assumption). The production functions for $\mathrm{R}$ and $\mathrm{T}$ are written as

$$
\begin{array}{lll}
Y_{R}(Q)=\frac{L_{R}}{\gamma_{R} Q^{\varepsilon_{R}}}, & 0<\gamma_{R}<\gamma_{N}, & 1 \leq \varepsilon_{R}<\varepsilon_{N} \\
Y_{T}=\frac{L_{T}}{\gamma_{T} Q^{\varepsilon_{T}}}, & \gamma_{T}>\gamma_{S}, & \varepsilon_{T}>\varepsilon_{S}
\end{array}
$$

and the associated average cost functions as

$$
\begin{aligned}
& A C_{R}(Q)=w_{R} \gamma_{R} Q^{\varepsilon_{R}} \\
& A C_{T}(Q)=w_{T} \gamma_{T} Q^{\varepsilon_{T}} .
\end{aligned}
$$

Our assumptions about technology dictate that a necessary condition for each country to be able to produce some varieties of the differentiated good at a lower cost than the other countries is that wages are lowest in $T$ and highest in $R$, that is $w_{R}>w_{N}>w_{S}>w_{T}$. In Figure 2 we depict the relationship between average cost and quality for the four countries. The assumption that $\mathrm{T}$ has the lowest wage allows this country to produce at the lowest cost all varieties with quality in the range $\left[1, Q_{T S}\right]$. This is a manifestation of the assumption that $\mathrm{T}$ has comparative advantage in lowquality varieties of the differentiated good. 


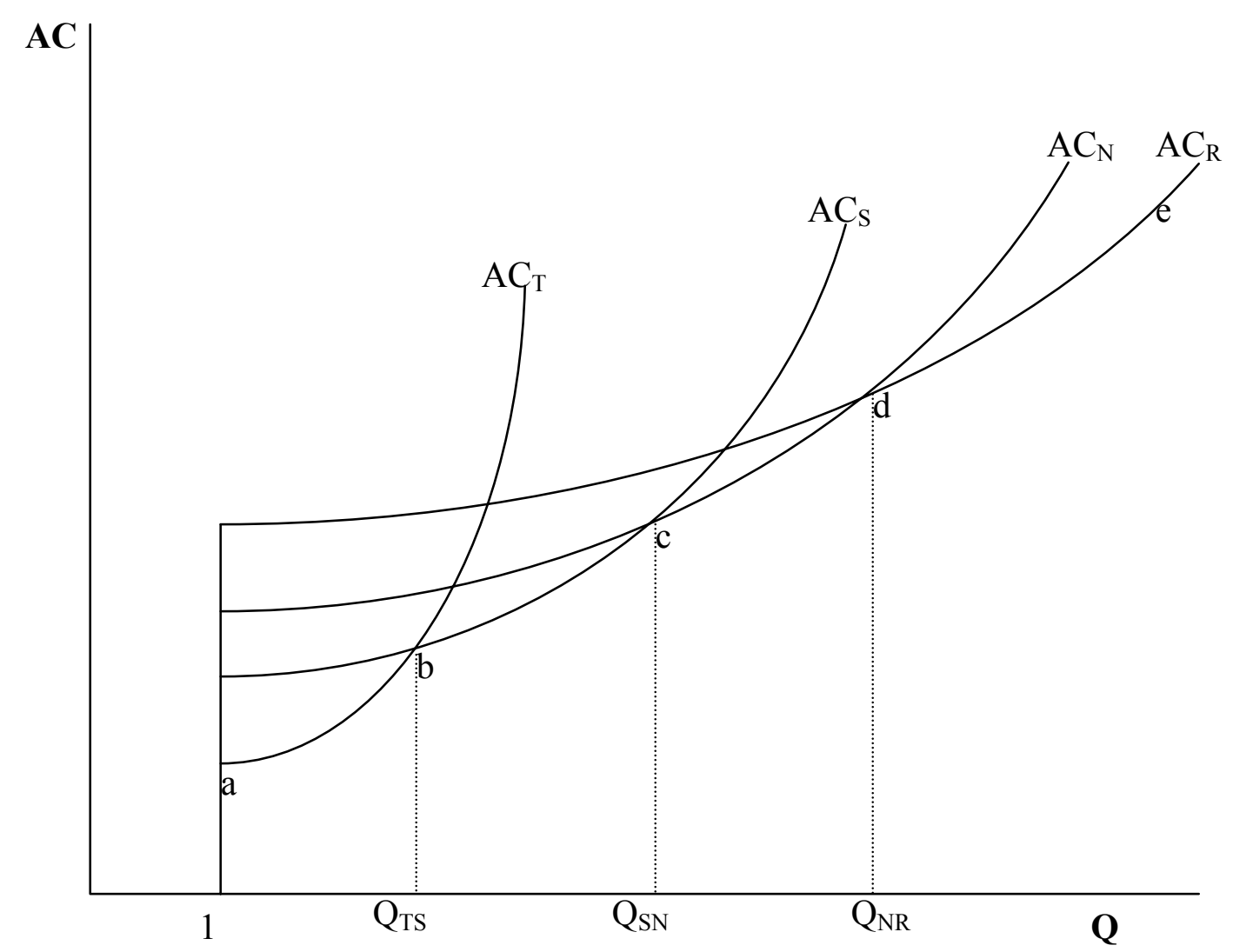

Figure 2: Cost-quality schedules

We define $Q_{T S}$ as the market-dividing quality level between T's and S's producers. On the other hand, $\mathrm{R}$ will be the least cost producer for varieties with quality greater than, $Q_{N R}$ i.e., $\mathrm{R}$ has comparative advantage in very high-quality varieties. Similarly, the South's and the North's comparative advantage is restricted to middle-quality varieties and high-quality varieties, i.e. those ones with quality in the ranges $\left[Q_{T S}, Q_{S N}\right]$ and $\left[Q_{S N}, Q_{N R}\right]$, with $Q_{S N}$ and $Q_{N R}$ being the market-dividing quality levels between Southern and Northern producers, and Northern and rest of the world (ROW) producers, respectively. From Figure 1 it also becomes obvious that the "competitive threat" to a country's producers is only from those foreign producers, which have comparative advantage in supplying contiguous (in terms of quality) varieties.

The above representation of technological differences between countries is an attempt to capture the "average" situation in terms of vertical product specialization between the countries involved. It is obvious that there are some products for which Turkey may have comparative advantage in producing higher quality varieties than the EU countries or the ROW. This is may also be due to the transfer of technology through 
foreign direct investment (FDI) from (mainly) EU countries. In many cases FDI is associated with the international fragmentation of the production process (see, Jones (2000)). In these instances, a country may acquire a comparative advantage in producing high quality varieties of some intermediate inputs (components), without necessarily having comparative advantage in the production of high quality varieties of other components or of the final product. There is indeed evidence that such processes may have been at work in Turkey, but, as yet (circa 2002), the contribution of FDI to the upgrading of domestically produced varieties has not raised average quality to the level observed in the least technologically advanced EU countries ${ }^{9}$.

\section{2.1 The Effects of Customs Union Expansion}

International trade between the four countries will involve the exchange of different quality varieties - since, for example, there will be some low-income Northern EU residents wishing to consume low quality varieties produced at the lowest cost in $\mathrm{T}$, and some very-high income households in $\mathrm{T}$ wishing to buy varieties which are produced at the lowest cost in $\mathrm{R}$. The distribution of income thus plays a crucial role in the analysis in that households with identical preference structures may nevertheless consume varieties produced in different countries if they have different incomes.

We start our analysis by assuming the existence of a $\mathrm{CU}$ between $\mathrm{N}$ and $\mathrm{S}$, and that there is a CET, $\boldsymbol{t}$. In Figure 3 , we depict the consequences of an enlargement of the $\mathrm{CU}$ between $\mathrm{N}$ and $\mathrm{S}$, to include $\mathrm{T}$. Before the enlargement, the price schedule facing consumers in $\mathrm{N}$ and $\mathrm{S}$ is depicted by the kinked line abcde. The curves $p_{T}+t$ and $p_{R}+t$ depict the tariff inclusive prices that producers in T and R charge to N's and S's consumers. Under these circumstances, the range of varieties, which $\mathrm{T}$ will be exporting to $\mathrm{N}$ and $\mathrm{S}$, will be up to $Q_{T S}^{0}$, whereas $\mathrm{R}$ will be exporting to $\mathrm{N}$ and $\mathrm{S}$ all varieties with quality greater than $Q_{N R}$. After the accession of $\mathrm{T}$ to the $\mathrm{CU}$, the price schedule and the budget constraint facing N's and S's consumers are given by the

\footnotetext{
${ }^{9}$ Flam (2003) notes that the amount of FDI flows to the Turkish economy is far below the level attracted by the more successful CEECs. Indeed, for the period 1995-2000, the total FDI inflows to Turkey were 4,079 million euros, whereas the FDI inflows to Poland (whose population is less than 60\% of Turkey's population) amount to 25,526 million euros (Eurostat (2002)). According to UNCTAD (2002), Turkey has one of the lowest rankings in terms of its potential for FDI inflows. Nevertheless, FDI inflows to Turkey are expected to increase as the day of full EU membership draws closer.
} 
kinked line fgcde in both Figures. The range of varieties which now $\mathrm{T}$ exports to $\mathrm{N}$ and S expands up to $Q_{T S}^{1}$, whereas S's range of varieties that it supplies at the lowest cost in the N's and S's market (the EU15 market) diminishes by the same amount (e.g. distance $\left.Q_{T S}^{0} Q_{T S}^{1}\right)$.

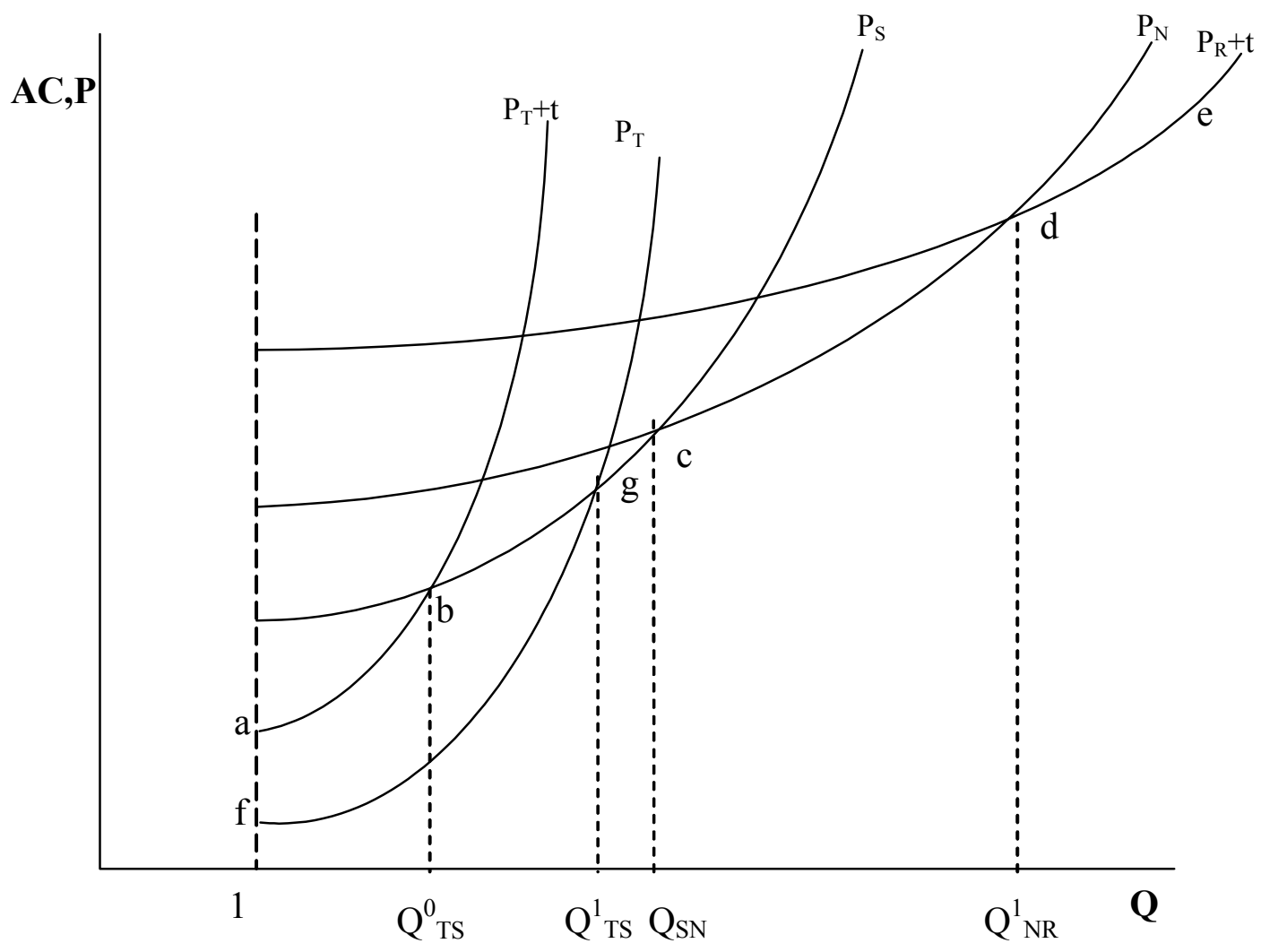

Figure 3: $C U$ expansion with verticallydifferentiated products

In Figure 4 we depict the consequences of the CU for Turkey's market. S's export share in this market increases at the expense of local production - the range of South's exports increases by the distance $\mathrm{Q}^{0}{ }_{\mathrm{TS}} \mathrm{Q}^{1}{ }_{\mathrm{TS}}$. The N's export share in Turkey's market also increases - at the expense of ROW exports by the distance $Q^{0}{ }_{N R} Q^{1}{ }_{N R}$.

In summary, the enlargement to include $\mathrm{T}$ into the $\mathrm{CU}$ results in an increase in Northern and Southern exports to $\mathrm{T}$ and an increase of T's exports to $\mathrm{N}$ and $\mathrm{S}$. However, the increase in T's exports is done at the expense of South's producers only. Higher sales of T's producers into the EU's market displace only Southern produced varieties - North's exports (and sales in the domestic market) do not decline ${ }^{10}$.

\footnotetext{
${ }^{10}$ The model could be easily amended to accommodate the existence of (economic) profits in two ways. First, we could maintain the hypothesis of a large number of firms, so that each one is a price-taker, with
} 


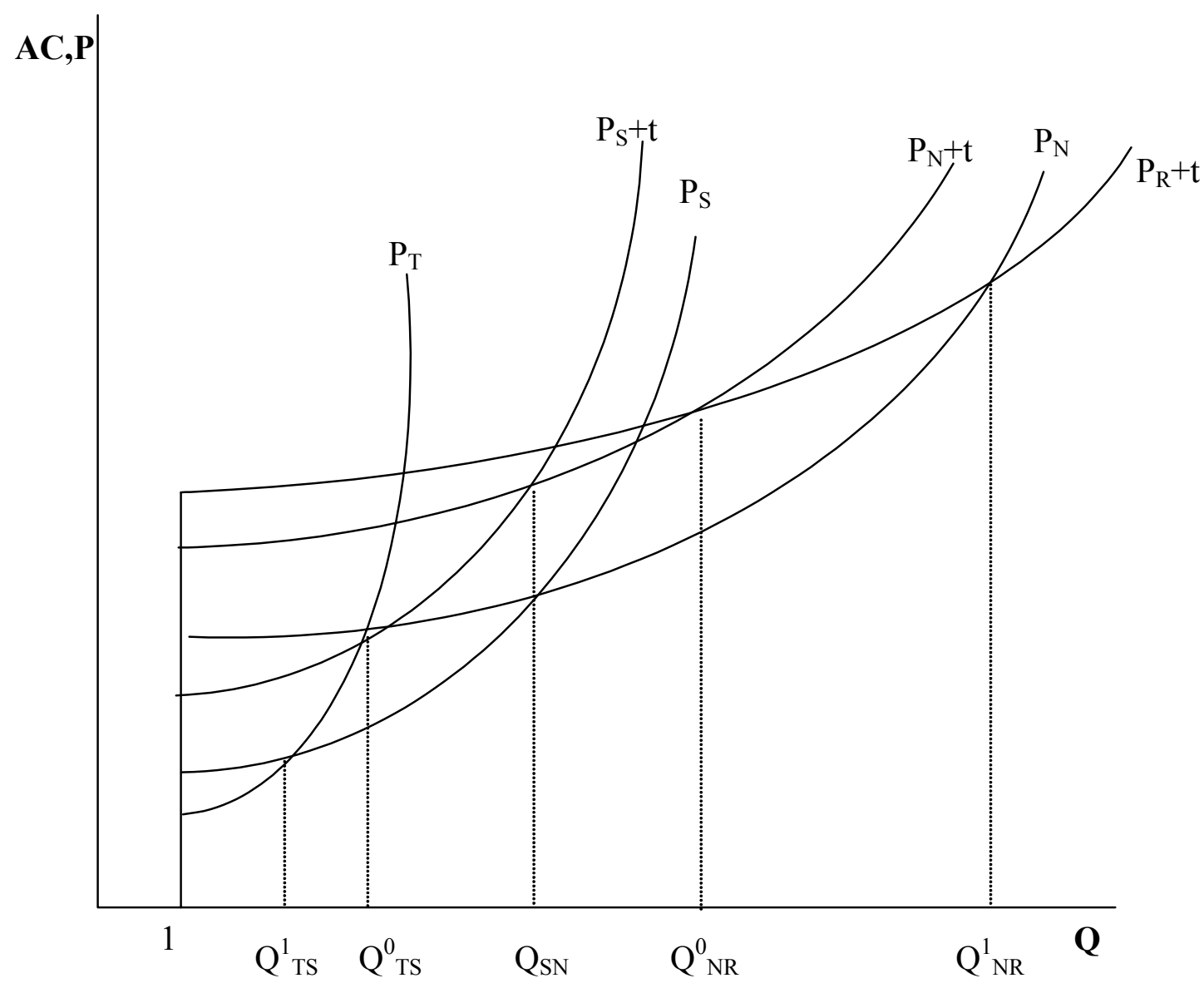

Figure 4: $C U$ expansion with vertically-differentiated products

\section{Empirical Analysis}

In order to empirically assess the effects of the customs union between the EU and Turkey on the export performance of each EU(15) country to the other fourteen countries, we estimated a gravity model comprising of all fifteen EU countries for the

some of them being more productive than others (a model of pure competition). The more productive firms will be earning profits in equilibrium (infra-marginal firms), and they will be interested in an expansion of demand, which would allow higher cost firms to enter the industry thereby raising the equilibrium price above the average cost of infra-marginal firms and allowing them to increase their profits further. Second, and more realistically, we can consider a model of oligopoly in which firms choose the price-quality combination, which maximizes profits. In this model, the elimination of tariffs on imports from $\mathrm{E}$ results in reductions in the prices that $\mathrm{G}, \mathrm{D}$ and $\mathrm{R}$ firms charge to consumers in the incumbent countries, in an effort to maintain their market share. Despite these complications, the prediction of the competitive model (that the North's net exports increase if $\mathrm{T}$ accedes to the $\mathrm{CU}$ ) remains intact. 
period 1988-2002. ${ }^{11}$ The time period was chosen to ensure availability and reliability of sectoral data for the entire country sample (including Turkey), and to exclude the effects of previous enlargments (or customs union agreements) of the EU. ${ }^{12}$

According to our theoretical framework, we examine the effects of the EU- Turkey agreement on the exports of each EU15 country i to the rest of the EU15 countries (we denote this as $\left.\mathrm{X}_{\mathrm{i}, \mathrm{EU} 15-\mathrm{i}}\right)$. We estimate a gravity equation of the following form:

$$
\begin{aligned}
& X_{i, E U 15-i, t}=\beta_{o}+\beta_{1} \log \left(Y_{i t} Y_{E U 15-i, t}\right)+\beta_{2} \log \left(P_{i t} P_{E U 15-i, t}\right)+\beta_{3} d R E E R_{i t}+\gamma T U R_{E U 15-i, t}+ \\
& +\beta_{5} C E E C+\mu_{i, E U 15-i}+\lambda_{t}+e_{i t} \\
& \mathrm{X}_{\mathrm{i}, \mathrm{EU} 15-\mathrm{i}, \mathrm{t}}=\text { Log of the real manufacturing exports of country } \mathrm{i} \text { to EU15-i } \\
& \mathrm{Y}_{\mathrm{it}} \mathrm{Y}_{\mathrm{EU15}-\mathrm{i}, \mathrm{t}}=\text { Log of real GDP of country } \mathrm{i} \text { at time } \mathrm{t} \text { times real GDP EU15-i } \\
& \mathrm{P}_{\mathrm{jt}} \mathrm{P}_{\mathrm{EU15} \text {-i,t }}=\text { Log of population of country } \mathrm{i} \text { at time } \mathrm{t} \text { times population EU15-i } \\
& \mathrm{dREER}_{\mathrm{it}}=\text { Rate of change of the Real Effective Exchange Rate of country } i \\
& \text { CEEC = Dummy, equal to } 1 \text { after } 1993 \text { or the Exports of the CEECs to the } \\
& \text { EU15-i market } \\
& \mu_{\mathrm{i}, \text { EU15-i }}=\text { Time Invariant- Country Specific effect } \\
& \lambda_{\mathrm{t}}=\text { Country Invariant- Time Specific effect. }
\end{aligned}
$$

Exports data are taken from OECD's STAN Bilateral Trade database. The coverage of the STAN data begins in 1988 and the latest year available is 2002. The REER data are taken from OECD's Main Economic Indicators and GDP and population data are taken from OECD’s Economic Outlook. In a typical gravity model, besides the so- called "gravity" variables (i.e., real income and population), a series of dummies and time invariant variables are included, i.e. distance, common language, border dummies, common currency, etc. Moreover, during the time period under consideration (19882002) there were major developments in the world economy that have also affected the intra- EU trade flows, eg., the rise of China as an important actor in the world trading system, and the integration of the CEECs in the world economy. This implies that our econometric model will be correctly specified only if we include a series of time

\footnotetext{
${ }^{11}$ Despite its simplicity, the gravity model is widely used in empirical trade theory since it fits well to any theory of international trade from Heckscher-Ohlin to new trade theories (see, Deardorff (1998)). 12 The Customs Union between the EU and Austria, Finland and Sweden had been formed well before 1993 (which is the date of entry of these three countries to the EU).
} 
specific- country invariant variables to account for these shocks. Since the list of both the time invariant and the country invariant variables can be rather exhaustive, we take the simplest shortcut by assuming that the correct specification of our panel data model is a Fixed- Effects, Two Way Error Component model ${ }^{13}$. Accordingly, the country specific fixed effects, $\mu_{\mathrm{iEU} 15-\mathrm{i}}$, include all the time invariant variables (distance, common language etc.), whereas the time specific fixed effects, $\lambda_{t}$, include all the country invariant "shocks" to world trade. The proper estimator for our model then is the two- way within estimator, that wipes out $\mu_{\mathrm{i}, \mathrm{EU} 15-\mathrm{i}}$ and $\lambda_{\mathrm{t}}$. The Fixed-Effects, TwoWay error component model is also supported both by our econometric testing (i.e. a Hausman test that rejects the null of the random effects in favour of the fixed effects estimator), and by an F- test that shows that the country and time specific effects are statistically significant in all estimated equations (see also Mátyás 1997, 1998). We note that the fixed effect $\mu_{\mathrm{iEU} 15-\mathrm{i}}$ of country $i$ is expressed in relative (to the EU15-i) terms $^{14}$.

According to the gravity equation, the "normal" amount of trade among two countries depends on the product of the size of their economies and on the economic, geographic and cultural distance between the two economies. The trade creating or diverting effects of a CU agreement are usually measured by adding a dummy variable for the participation in the agreement (see, Frankel (1997)). However this may not constitute a correct empirical strategy in our case for the following two reasons. ${ }^{15}$ First, the EUTurkey CU agreement came into effect in 1996, whereas the EU- CEECs agreements (the so-called Europe Agreements) started coming into effect from 1994 onwards ${ }^{16}$ and their trade creating effect for the CEECs became gradually apparent in the following years (see Adam et al (2004) for a discussion). Thus allowing for a dummy variable to measure the effect of the EU- Turkey agreement may not be appropriate since the

\footnotetext{
13 The dependent variable is exports of each country to the EU15-i market. In this case the bilateral fixed effect $\mu_{\mathrm{i}, \mathrm{EU} 14-\mathrm{i}}$ is equivalent to having separate country $\mathrm{i}$ and country $\mathrm{j}$ fixed effects, as in Baltagi et. al. (2003).

14 This is consistent also with the trade theoretic methodology where all variables affecting trade are expressed in relative terms.

${ }^{15}$ Nevertheless, it is worth mentioning that we have verified that the qualitative nature of our empirical findings remains unaltered to following this strategy. Table A1 in the appendix shows the econometric results for this case.

${ }^{16}$ The Europe Agreements for Hungary and Poland entered into force on 1 February 1994, and those for Bulgaria, the Czech Republic, Romania, and the Slovak Republic on 1 February 1995. Bilateral freetrade agreements were also signed with Estonia, Latvia and Lithuania in 1994, which came into effect in 1995.
} 
effects of the EU- Turkey agreement would potentially coincide with the effects of the Europe Agreements. Second, the EU- Turkey agreement did not involve immediate liberalization of trade for all sectors, but instead it involved for most of them a gradual liberalization strategy.

For these reasons we have decided to derive endogenously a measure for the increase in EU-Turkey trade that can be attributed to their CU. In order to do this we proceed as follows. First, we estimate a similar gravity model as in equation (9) for the 19881995 period, with Turkey's exports to EU15-i as the dependent variable. We then use the estimated coefficients in order to perform an out-of-sample prediction for the 19962002 period in order to find the "normal" amount of exports of Turkey to EU15-i (i.e., our prediction for the amount of exports which would obtain if the CU agreement did not take place). As a final step, we measure the impact of the CU agreement as the difference between the actual and the predicted values of Turkey's exports to EU15-i for the 1996-2002 period. $^{17}$ This is variable TUR in equation (9) ${ }^{18}$. We expect this variable to have a negative impact on the exports of country $i$ to the EU15-i, due to the displacement of intra-EU15 trade that the granting of preferetial access to Turkey's exports to the EU should generate. Nevertheless, what is more important according to our theoretical priors, is the possibility of an assymetric effect across the EU15 countries, depending on their degree of export similarity with Turkey and their level of technological sophistication. We implement this below by allowing for the coefficient of this variable to vary across the low technology and high technology countries.

In Table 2 we present the results when we allow for a homogeneous effect of the extra Turkish exports to EU15 on the exports of each of the EU15 countries to the other 14 countries (same $\gamma$ across for all EU15 countries). In Table 2 we also report the Random Effects estimates of the model. The comparison of the outcomes of both estimations is a natural test of the robustness of the results. All variables have the expected sign.

\footnotetext{
${ }^{17}$ Of course one may expect that the difference between predicted and actual exports may be affected by time specific effects, for the reasons mentioned in connection to the specification of equation (9). However, since our method for computing TUR involves the estimation of the model only for the 19881995 period, it is not possible to have an estimate of the time effects for the 1996- 2002 period. To capture as much as possible the time specific effects for this period, we include in the equation for Turkey a common time trend.

${ }^{18}$ We cannot perform the same procedure for the CEECs since there are no available bilateral trade data for these countries before 1991 .
} 
Since trade is expected to increase with size and per capita income, $\beta_{1}$ and $\beta_{2}$ are positive and negative respectively. Furthermore the estimated coefficients $\beta_{1}, \beta_{2}$ are very close to the ones obtained in the literature and consistent with the growth in world trade during the last 50 years (see, Frankel (1997)). What is worth noting is that the Europe Agreements seem to have had, on average, a low and statistically insignificant effect on the intra-EU exports. This may be because the Europe Agreements started coming into effect in 1994, and their effect was gradually becoming more significant. It is thus likely that much of the CEEC effect on intra-EU15 exports has been captured by the time specific effects introduced into our model. The influence of the real exchange rate is also found to be insignificant, a result which can be explained by the fact that most of the EU15 countries were participating in the Exchange Rate Mechanism, and there have been small differences in the behaviour of their (multilateral) real exchange rate indices during this period.

\begin{tabular}{|c|c|c|}
\hline \multicolumn{3}{|c|}{ HOMOGENEOUS COEFFICIENTS } \\
\hline & FIXED EFFECTS & RANDOM EFFECTS \\
\hline & $X$ EU15 & $\underline{X E U 15}$ \\
\hline \multirow[t]{2}{*}{ YiYj } & $1.203^{\star \star \star}$ & $0.415^{\star \star \star}$ \\
\hline & $(7.51)$ & $(5.21)$ \\
\hline \multirow[t]{2}{*}{$\mathrm{PiPj}$} & $-1.749^{* * *}$ & 0.177 \\
\hline & $-(3.78)$ & $(0.9)$ \\
\hline \multirow{2}{*}{ dREER } & 0.438 & $0.826^{* \star *}$ \\
\hline & $(1.45)$ & $(2.78)$ \\
\hline \multirow[t]{2}{*}{ CEEC } & 0.009 & -0.042 \\
\hline & $(0.12)$ & $\begin{array}{l}-(1.17) \\
\end{array}$ \\
\hline \multirow[t]{2}{*}{ TUR } & $-0.027^{* * *}$ & $-0.025^{\star \star \star}$ \\
\hline & $-(3.46)$ & $-(2.86)$ \\
\hline R square & 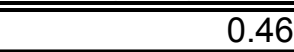 & 0.50 \\
\hline F test model & 8.21 & \\
\hline Chi-2 model & & 76.56 \\
\hline F test country & 33.26 & \\
\hline F test time & 4.36 & \\
\hline Hausman FE & 10.84 & \\
\hline obs & 203 & 203 \\
\hline \multicolumn{3}{|c|}{$\begin{array}{l}\text { Note:Two way Fixed Effects and Random Effects, t statistics in } \\
\text { the parenthesis. }{ }^{*}=10 \%,{ }^{* *}=5 \%,{ }^{* * *}=1 \% \text { significance. }\end{array}$} \\
\hline
\end{tabular}

Table 2: Gravity Model Estimation, Exports to the EU15 Market

The results in Table 2 suggest that, as expected, the increased integration of Turkey with the EU decreased the exports of each of the EU15 countries to the other 14 countries by a negligible amount: combining the average value of the TUR variable (i.e., the above normal increase in Turkish exports to the EU during the 1996-2002 
period), which is about $11 \%$, with the estimated coefficient for this variable ${ }^{19}$, we find that the EU- Turkey CU has resulted in a negligible reduction (about one thirtienth of one percentage point) in the average exports of each of the EU15 countries to the rest of the EU. ${ }^{20}$

We now proceed to test for the existence of asymmetric effects on the exports of each of the EU15 countries to the rest of EU. To test for this asymmetry we assume that the coefficient $\gamma$ in equation (9) is not the same for all EU15 countries. We expect that for the group of countries that face more competition from Turkey and have a lower technological sophistication, the Turkish accession will have a greater (negative) effect on their exports. To identify such a group we develop measures reflecting the degree of competition that countries face from Turkey as well as a measure of the technological sophistication of each EU15 country.

To measure the degree of competition between each of the EU15 countries and Turkey, we use a measure of the extent to which Turkey's exports overlap with the exports of each EU15 country as in Finger and Kreinin (1979) and Lee (1997):

$$
E S_{(i, T, E U 15-i)}=\sum_{j}\left|E X_{j, i, E U 15-i}-\frac{E X_{j, i, E U 15-i}+E X_{j, T, E U 15-i}}{2}\right|
$$

This index measures the degree of export similarity (ES) between Turkey and each EU country $\mathrm{i}$ regarding their exports to the rest of the EU15 countries. EX $\mathrm{J}_{\mathrm{j}, \mathrm{i}, \mathrm{EU} 15-\mathrm{i}}$ is the share of manufacturing commodity group $\mathrm{j}$ in the total manufacturing exports of country $\mathrm{i}$ (or $\mathrm{T}$ for Turkey) to the EU15-i. To compute this index we used the disaggregated SITC 4 digit data taken from OECD's ITCS Trade by Commodity Database $^{21}$, which involve 533 product groups, for the time period 1995- 2002 for each

\footnotetext{
${ }^{19}$ The TUR coefficient is considered robust since it has the same sign, magnitude and statistical significance in the Random Effects model as well.

${ }^{20}$ In all the estimations that follow we are reporting the estimated change in exports according to the point estimates of TUR. However the coefficient of TUR belongs to a confidence interval and the size of this interval depends on the standard error of TUR. Accordingly, the estimated change in exports (coefficient of TUR times the value of TUR) will also fall within a confidence interval the size of which depends on the size of the confidence interval of TUR. Nevertheless, our finding of asymmetries in this paper should be considered robust since the difference in the TUR coefficients between the North and the South is statistically different from zero.

21 As available online in http://www.sourceoecd.com
} 
EU15 country ${ }^{22}$. Lower values of ES correspond to a more identical commodity distribution of exports and thus higher competition in the common EU market.

In Figure 5 we depict the average value of the ES index for each EU15 country vis-àvis Turkey the period 1995-2002. Figure 5 suggests that the countries whose exports overlap most with Turkish exports in the EU market are Greece, Portugal, Italy, Spain and France.

\section{Export Similarity Index}

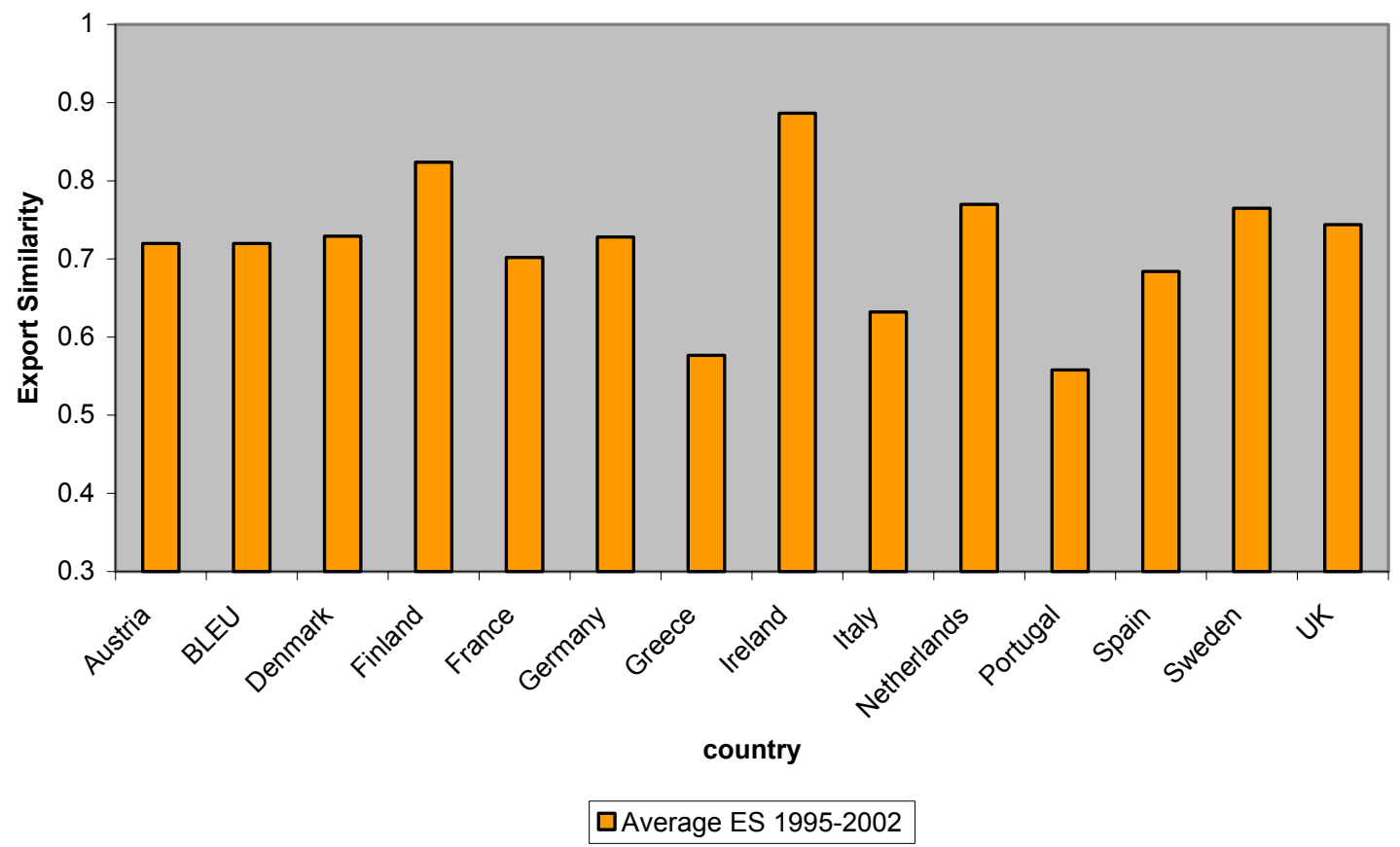

Figure 5: Manufacturing Export Similarity

We now proceed to construct a measure of technological sophistication for each of the EU15 countries and Turkey. To do so, we used 5- digit data of world manufacturing exports (SITC categories 5 to 8, which include a total of 1023 industries) and imports of each country, taken from OECD's ITCS Trade by Commodity Database. Then for each industry $\mathrm{j}$ we computed the trade overlap index defined as:

22 The export similarity index appearing in equation (10) has the advantage that it is semi- metric and it is equivalent to the Bray- Curtis semi- metric index which has been largely used also in the natural sciences (De Benedictis and Tajoli, 2003). An alternative measure one could use to measure the similarity of exports of two countries is the Pearson's coefficient of correlation between the export shares of each industry of country $i$ and $T$. This measure however is rather inappropriate since the export shares are skewed, and the Pearson's coefficient of correlation depends on the mean of the distribution. 


$$
T O I_{i j t}=\frac{\min \left[M_{i j t}, X_{i j t}\right]}{\max \left[M_{i j t}, X_{i j t}\right]},
$$

where $\mathrm{M}_{\mathrm{ijt}}$ and $\mathrm{X}_{\mathrm{ijt}}$ are world imports and exports of product $\mathrm{j}$ in country $\mathrm{i}$ at time $\mathrm{t}$ respectively. When the $\mathrm{TOI}_{\mathrm{ijt}}$ is greater than $10 \%$ the exports of industry $\mathrm{j}$ are classified as Intra- Industry Exports. We then calculated the average unit value of exports to imports for all industries of country $i$ at time $t$, for all industries that are involved in intra-industry trade. Industries for which this ratio was greater than 1.15, were classified as industries involved in the exportation of high-quality, verticallydifferentiated products (see, Greenaway et al. (1995)). Industries for which this ratio was below 0.85 , their exports were classified as low-quality exports. For all remaining industries (those with relative unit values between 0.85 and 1.15), their exports were considered to be same-quality exports (i.e., these industries were involved in trade in horizontally differentiated products). Adding up the manufacturing exports of all highquality industries and dividing them by the total amount of the vertically-differentiated manufacturing exports of country $i$, we obtained a measure of technological sophistication for country $i$ at year $t$, i.e. the share of high-quality manufacturing exports to total vertically-differentiated manufacturing exports. In Table 3, the first column presents the average 1995-2002 value of this index with higher values implying superior technology. The second column ranks all EU15 countries and Turkey according to the average 1995-2002 value of this technology index. In the third column of Table1 we rank the EU15 countries according to their export similarity index (the average for the 1995-2002 period), with higher values in the ranking implying a higher export similarity with Turkey. 


\begin{tabular}{|c|c|c|c|}
\hline & $\begin{array}{l}\text { Technology } \\
\text { Index }\end{array}$ & \begin{tabular}{|l} 
Technology \\
Ranking
\end{tabular} & $\begin{array}{l}\text { ES } \\
\text { Ranking }\end{array}$ \\
\hline Germany & 0.790 & 1 & 7 \\
\hline Ireland & 0.754 & 2 & 1 \\
\hline UK & 0.740 & 3 & 5 \\
\hline Denmark & 0.734 & 4 & 6 \\
\hline$B L E U$ & 0.731 & 5 & 8 \\
\hline Netherlands & 0.722 & 6 & 3 \\
\hline Sweden & 0.698 & 7 & 4 \\
\hline Austria & 0.687 & 8 & 9 \\
\hline France & 0.681 & 9 & 10 \\
\hline Finland & 0.533 & 10 & 2 \\
\hline Greece & 0.531 & 11 & 13 \\
\hline Italy & 0.465 & 12 & 12 \\
\hline Spain & 0.431 & 13 & 11 \\
\hline Portugal & 0.403 & 14 & 14 \\
\hline Turkey & 0.243 & 15 & 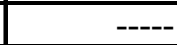 \\
\hline
\end{tabular}

Table 3: Country technology and export similarity rankings

From Table 3 we see that not only Greece, Italy, Spain and Portugal have the lowest technology ranking among the EU15, but they are also the countries for which their export pattern is the most similar to Turkey's ${ }^{23}$. We will term this group of countries as South 1. Table 3 also reveals that France's positioning in both the technology and export similarity rankings, may justify its inclusion in the South. We term the group consisting of the South 1 countries plus France, as South 2.

In Table 4 we present the results of estimating the same gravity model, but this time we allow $\gamma$ to vary between the two country groups (North and South). We expect that the negative effect of the EU-Turkey CU -as far as the intra-EU15 exports are concerned- will be more pronounced for the South than for the North. In the top part of the Table 3, we report the coefficients for the North. The coefficients for the South are expressed as deviations from the North. As Table 4 reveals, the effect on the South (either South1, or South2) is significantly different from that of North. For the South the effect of an increase in the Turkish exports to EU15 is negative and statistically significant (at the 1\% level), whereas for the Northern countries it is both economically

\footnotetext{
${ }^{23}$ It must be mentioned that these "technology rankings" by no means should be interpreted as reflecting a country's overall level of technological sophistication, but only as a measure of the relative technological sophistication of their exports. For example, Greece does not possess the technological capacity to produce passenger cars at a quality-cost combination which would make them attractive to either the domestic or foreign markets. Yet, countries that do have this technological capacity (eg., Italy or Spain) export -on average- lower-priced varieties than they import, and this has a negative impact on the technology ranking of these countries (especially if this commodity brings in a significant amount of export earnings).
} 
negligible and statistically insignificant. The estimated coefficients imply that a $1 \%$ increase in Turkey's exports to the EU15 above their "normal" level results into a $0.26 \%$ reduction in the average exports of each of the Southern countries to the rest of the EU15. Moreover all coefficients of interest (TUR, south1 TUR and South2 TUR) can be considered robust as they have the same sign and significance when the model is estimated with Random Effects.

\begin{tabular}{|c|c|c|c|c|}
\hline \multicolumn{5}{|c|}{ HETEROGENEOUS COEFFICIENTS } \\
\hline & \multicolumn{2}{|c|}{ FIXED EFFECTS } & \multicolumn{2}{|c|}{ RANDOM EFFECTS } \\
\hline \multirow[t]{2}{*}{\begin{tabular}{|l|l}
$\mathrm{Yi} j$ \\
\end{tabular}} & $1.089^{\star \star \star}$ & $1.066^{\star \star \star *}$ & $0.842^{* * *}$ & $=0.824^{\star * \star}$ \\
\hline & $(5.42)$ & $(5.26)$ & $(5.32)$ & $(5.19)$ \\
\hline \multirow[t]{2}{*}{$\mathrm{PiPj}$} & $-1.716^{\star * *}$ & $-1.746^{\star * *}$ & -0.167 & -0.158 \\
\hline & $-(3.69)$ & $-(3.75)$ & $-(0.73)$ & $-(0.69)$ \\
\hline \multirow[t]{2}{*}{ dREER } & 0.372 & 0.389 & 0.335 & 0.348 \\
\hline & $(1.23)$ & $(1.28)$ & $(1.07)$ & $(1.1)$ \\
\hline \multirow{2}{*}{ CEEC } & -0.180 & -0.147 & $-0.255^{*}$ & $-0.233^{*}$ \\
\hline & $-(1.00)$ & -(0.82) & $\begin{array}{l}-(1.93) \\
-(1.93\end{array}$ & $-(1.78)$ \\
\hline \multirow[t]{2}{*}{ TUR } & -0.035 & -0.050 & -0.046 & -0.061 \\
\hline & $-(0.38)$ & $-(0.55)$ & $-(0.56)$ & $-(0.73)$ \\
\hline \multicolumn{5}{|c|}{ DEVIATIONS FROM NORTH } \\
\hline \multirow[t]{2}{*}{ South1 TUR } & $-0.228^{* * *}$ & & $-0.221^{* * *}$ & \\
\hline & $-(2.62)$ & & $-(2.62)$ & \\
\hline \multirow[t]{2}{*}{ south2 TUR } & & $-0.201^{* *}$ & & $-0.193^{\star *}$ \\
\hline & & $\begin{array}{l}-(2.31) \\
-(21)\end{array}$ & & $\begin{array}{l}-(2.28) \\
-(28)\end{array}$ \\
\hline R square & 0.47 & 0.47 & 0.46 & 0.37 \\
\hline F test model & 8.05 & 7.90 & & \\
\hline Chi2 model & & & 110.42 & 134.26 \\
\hline$F$ test country & 292.67 & 291.00 & & \\
\hline F test time & 2.41 & 2.36 & & \\
\hline Hausman FE & 20.64 & 20.76 & & \\
\hline obs & 203 & 203 & 203 & 203 \\
\hline
\end{tabular}

\section{Table 4: Exports to EU14 market, different coefficients}

In order to assess the magnitude of the EU- Turkey CU effect on the exports of the South, we computed the average value of the increase in the exports of Turkey to the EU15 that can be attributed to the CU (i.e., the increase in Turkey's exports to the EU15 which is above their "normal" level as predicted by the gravity model); this is our definition of the TUR variable. When we define the South as South1, the average TUR is close to $26 \%$ and statistically significant. Using the point estimates from Table 4, we find that as a result of the CU, the average exports of each country of South1 to the rest of the EU15 fell by about 7\%. On the other hand, the impact on the average 
value of exports of each country of the North to the rest of the EU15 is found to be both economically negligible and statistically insignificant at the 5\% level of significance. When we define the South as South2, the average TUR is $25 \%$, statistically significant, and it implies that the average exports of each country of South2 to the rest of the EU15 fell by about 6\%. The corresponding effect for the North is again found to be both economically negligible and statistically insignificant.

The above findings indicate that as far as the intra-EU exports of the EU15 are concerned, the EU-Turkey $\mathrm{CU}$ had an asymmetric effect, the nature of which is consistent with our theoretical framework. Yet, in order to be able to suggest that the distribution of the benefits (or costs) of the EU-Turkey CU is uneven among the EU15 countries, we must examine whether the crowding-out of the intra-EU exports for the Southern group was not more than offset by a higher increase of its exports to Turkey.

In order to do this we estimated the same gravity model (as in equation (9)) for the period 1989- $1995^{24}$, with the exports of each EU15 country to Turkey as the dependent variable ${ }^{25}$. The difference between actual exports and the out-of-sample prediction for the exports for each EU15 country to Turkey, for the period 1996-2002, is again taken to measure the degree of extra- penetration of the EU15 to Turkey due to the CU. The average value of the extra exports for each of the EU15 countries has been estimated to be about $26 \%$, which is also statistically significant. Defining the South as South1, the average value (of the increase in the South's exports is about $11 \%$, which is also statistically significant. On the other hand the average gain for the Northern group of countries in this case is about $32 \%$, this being also statistically significant. Moreover we cannot reject the hypothesis that the average gain of the North is higher than the average gain of the South. Finally, when we assume that the South is defined as South2, we find that the average value of the above "normal" increase of exports for the South is $13 \%$ and for the corresponding variable for the North is $29 \%$. Again, we find that we cannot accept the hypothesis of equality in the (above "normal") increase

\footnotetext{
${ }^{24}$ Data for the exports to Turkey were not available for 1988.

${ }^{25}$ The results of this estimation are summarized in the appendix (table A2, column II). Also in table A2 in the appendix we report the results of the gravity equation for the exports of each EU country to Turkey when we measure the effect of the Turkey- EU CU with a dummy variable that takes the value of 1 after 1996 (column I). Furthermore, columns III and IV reveal that the effects of the EU- Turkey CU did not have a differential impact on the South's (vis-à-vis the North's) exports to Turkey.
} 
in the exports of North and South2, against the alternative of a higher increase in Northern exports.

The above evidence suggests that not only the Southern group of countries had to face (on average) a decline in its exports to the rest of the EU15 countries as a result of the EU-Turkey CU - against the absence of a corresponding effect for the Northern group, but also the average (above "normal") increase of exports of the Southern group to Turkey were smaller than for the Northern group.

Finally, and as an example of how asymmetric the effects of the EU-Turkey CU can be on countries that occupy the opposite sides in the technological spectrum, we consider the effects on Germany and Greece, respectively. The effect on Germany's exports to the other EU15 countries, as a result of the increase in Turkish exports to the rest of the EU15, is found to be both economically and statistically insignificant. The above "normal" increase of German exports to Turkey is estimated to be economically important (about 25\%) and statistically significant. On the other hand, the estimated reduction of Greek exports to the other EU15 countries as a result of the CU is estimated to be about 7\% (and statistically significant), whereas the (above "normal") increase of Greek exports to Turkey is estimated to be about $4 \%$.

\section{Conclusions}

The asymmetric effects of customs union expansion identified in this paper can be given an alternative and possibly broader interpretation. From the theory of international trade it is well known that trade liberalization can have a pervasive effect on factor returns. For example, in the specific factors model trade liberalization increases the real income of factors used exclusively in the production of the exportable good, reduces the real income of factors not used in the production of the exportable good, and it has an ambiguous effect on the real income of factors used in the production of both importable and exportable goods. With some sleight of hand we can think of firms residing in the North of EU15 as being the owners of the factor which is used exclusively in the production of the exportable good, whereas owners of firms in the South of the EU15 are the owners of the factor used exclusively in the production of the importable good. This interpretation is made possible by the fact that 
the South produces (and exports to the North) goods that are very similar to the goods exported by Turkey to the EU15 ; it is as if the South is the sector producing the importable good if we treat the EU15 as a single country. The asymmetric effects of the EU-Turkey CU identified in this paper can thus be also explained on the basis of a specific factors model in which the North and the South are identified as the sectors producing the exportable and importable goods, respectively.

According to this interpretation, the majority of firm owners in the North of the EU15 will be in favour of the EU-Turkey CU, whereas there will not be such a strong support among firm owners in the South. Moreover, if there is enough labour mobility between the two regions (or, sectors), then according to the specific factors model the effect on the real income of labour is ambiguous, whereas if labour mobility is limited, the interests of firm owners and workers will be aligned within each region (i.e., in regions producing mainly exportables (importables) both workers and firm owners will be favourable (against) the $\mathrm{CU}$ ). If the above observations are correct, then workers in the North (and, obviously in the South too) would not like to see the benefits (if any) which the CU has afforded them being jeopardized by lower wages and/or lower social benefits which may be the result of Turkish worker's migration to the North due to Turkey's full accession to the EU.

From a political economy perspective our analysis implies that whereas there was no apparent lack of political support for the EU-Turkey $\mathrm{CU}$, the political support for Turkey's full membership to the EU may be lacking. This may be not only because the governments of the EU countries do not want to see their relative power diminished as a result of the accession of a populous country. It may also be that the main beneficiaries from the EU-Turkey CU (i.e., mainly -but not exclusively- the owners of firms in the North of the EU) have already reaped most of the benefits due to the preferential access to the Turkish market that the CU has afforded to their products. Although these owners of specific factors may expect further benefits from the establishment of a "single market" with Turkey, these benefits may not be large enough to persuade the governments of the EU countries to ignore the fears of their workers that a rise in the relative (to capital) supply of labour in a EU27 plus Turkey economic union, will be detrimental to their wages. 


\section{References}

Adam, A. , Kosma T. and J. McHugh, 2003, "Trade Liberalization Strategies: What Could South Eastern Europe Learn from CEFTA and BFTA", IMF Working Paper No. 03/239.

Adam, A., and T. Moutos, 2004, "The Political Economy of EU Enlargement: Or, Why is Japan not a Candidate Country?", in H. Berger and T. Moutos (eds.), Managing European Union Enlargement, The MIT Press, Cambridge, Mass.

Baltagi B. H., P. Egger, and M. Pfaffermayr , 2003, A Generalized Design for Bilateral Trade Flow Models, Economics Letters, 80, 391- 397.

De Benedictis, L., and L. Tajoli, 2003, "Similarity and Convergence in the EU and CEECs Trade Structures", mimeo.

Deardorff, A.,1998, "Determinants of bilateral trade: Does gravity work in a neoclassical world?", in J.A. Frankel (ed.), The regionalization of the world conomy economy, The University of Chicago Press, Chicago.

Erzan, R., and A. Filiztekin, 1997, "Competitiveness of Turkish SMSEs in the Customs Union”, European Economic Review, 41, 88 1-892

European Commission, 2002, Regular Progress Report on Turkey, Brussels.

Eurostat, 2002, EU Direct Investment Yearbook, European Commission, Luxembourg.

Finger, J. M., and M.E. Kreinin, 1979, “A measure of "Export Similarity" and its Possible Use”, Economic Journal, 89, 905- 912.

Flam H., and E. Helpman, 1987, "Vertical Product Differentiation and North- South Trade", American Economic Review, 77, 810--822.

Flam, H., 2003, “Turkey and the EU: Politics and Economics of Accession”, CESifo Working Paper No. 893.

Frankel, J. A.,1997, "Regional Trading Blocs", Institute for International Economics, Washington, DC.

Greenaway, D., Hine, R.C, and Milner C.R., 1995, "Vetical and Horizontal Intra- Industry Trade: A Cross Industry Analysis for the United Kingdom", Economic Journal, 105, 15051518.

Greenaway, D., and C. Milner,2002, "Regionalism and Gravity", Scottish Journal of Political Economy, 49, 574- 585.

Harrison, G.W., T. F. Rutherford, D. G. Tarr, 1997, "Economic Implications for Turkey of a Customs Union with the European Union”, European Economic Review, 41, pp861-870.

Hartler, C., and S. Laird, 1999, "The EU Model and Turkey. A Case for Thanksgiving", Journal of World Trade, vol. 33, no. 3, pp. 147-165. 
Hughes, K., 2004, “Turkey and the European Union: Just Another Enlargement? Exploring the Implications of Turkish Accession", Friends of Europe Working Paper June 2004.

Lee, H., 1997, "A Perspective on the Effects of NAFTA on Korea", in T. Ito and A. O. Krueger (eds.), Regionalism versus Multilateral Trade Agreements, NBER East Asia Seminar In Economics, vol. 6, University of Chicago Press, Chicago.

Lejour, A.M. and R.A. de Mooij, 2004, “Turkish Delight: Does Turkey's Accession to the EU Bring Economic Benefits?”, CESifo Working Paper No. 1183.

Mátyás, L., 1997, "Proper econometric Specification of the Gravity Model”, The World Economy, 20, 363-68.

Mátyás, L., 1998, "The Gravity Model: Some Econometric Considerations", The World Economy, 21, 397-401.

Mercenier, J. and E. Yeldan, 1997, “On Turkey's Trade Policy: Is a Customs Union with Europe Enough?” European Economic Review 41, 871-880.

Panagariya, A., 2000, "Preferential Trade Liberalization: The Traditional Theory and New Developments", Journal of Economic Literature, 38, 287-331.

Togan, S., 1995, “Trade Policy Review of the Republic of Turkey", in S. Arndt and C. Milner (eds.), The World Economy Global Trade Policy, Blackwell, Oxford.

Togan, S., 1997, "Opening up the Turkish Economy in the Context of the Customs Union With the EU", Journal of Economic Integration, 12, 157-179.

Ulgen, S. and Y. Zahariadis, 2004, "The Future of Turkish-EU Trade Relations: Deepening vs Widening", EU-Turkey Working Papers, No. 5, Centre for European Policy Studies.

UNCTAD, 2002, World Investment Report 2002, New York and Geneva, United Nations. 
APPENDIX

\begin{tabular}{|c|c|c|c|}
\hline \multicolumn{4}{|c|}{ Table A1: Exports to EU14 Market (TUR dummy) } \\
\hline \multicolumn{4}{|c|}{ Dep. Variable Log Exports to EU14 } \\
\hline & ! & II & IIII \\
\hline \multirow[t]{2}{*}{ YiYj } & $1.092^{* * *}$ & $1.062^{* \star \star}$ & $1.074^{* \star \star}$ \\
\hline & $(6.75)$ & $(7.31)$ & $(7.10)$ \\
\hline \multirow[t]{2}{*}{$\mathrm{PiPj}$} & $-1.717^{* * *}$ & $-2.037^{* * *}$ & $-2.027^{* * *}$ \\
\hline & $(-3.60)$ & $(-4.73)$ & $(-4.50)$ \\
\hline \multirow[t]{2}{*}{ dREER } & 0.493 & $0.539^{*}$ & $0.542^{*}$ \\
\hline & $\overline{(1.58)}$ & $(1.93)$ & $(1.86)$ \\
\hline \multirow[t]{2}{*}{ CEEC } & 0.031 & 0.073 & 0.069 \\
\hline & $(0.38)$ & $(0.99)$ & $(0.90)$ \\
\hline \multirow[t]{2}{*}{ TUR dummy } & $-0.289^{* * *}$ & $-0.175^{* * *}$ & $-0.183^{\star *}$ \\
\hline & $(-3.16)$ & $(-2.08)$ & $(-2.09)$ \\
\hline \multicolumn{4}{|c|}{ DEVIATIONS FROM NORTH } \\
\hline \multirow[t]{2}{*}{ south1 } & & $-0.281^{* * *}$ & \\
\hline & & $(-6.54)$ & \\
\hline \multirow[t]{2}{*}{ south2 } & & & $-0.216^{\star * *}$ \\
\hline & & & $(-5.11)$ \\
\hline R square & 0.43 & 0.54 & 0.50 \\
\hline $\mathrm{F}$ test model & 7.52 & 11.20 & 9.59 \\
\hline F test country & 317.62 & 300.19 & 293.66 \\
\hline F test time & 4.37 & 5.53 & 5.13 \\
\hline Hausman FE & 20.66 & 37.06 & 35.49 \\
\hline obs & 203 & 203 & 203 \\
\hline
\end{tabular}




\begin{tabular}{|c|c|c|c|c|}
\hline \multirow{2}{*}{\multicolumn{5}{|c|}{ Table A2: Exports to Turkish Market Market }} \\
\hline \multirow{2}{*}{\multicolumn{5}{|c|}{ Dep. Variable Log Exports to Turkey }} \\
\hline & & & & IV \\
\hline \multirow[t]{2}{*}{$\mathrm{YiYj}$} & $1.036^{\star \star \star}$ & 0.576 & $1.026^{\star \star \star}$ & $1.021^{\star \star \star}$ \\
\hline & $(5.47)$ & $(1.34)$ & $(5.32)$ & $(5.32)$ \\
\hline \multirow[t]{2}{*}{$\mathrm{PiPj}$} & $-1.167^{\star * *}$ & -0.567 & $-1.150^{* * *}$ & $-1.140^{* * *}$ \\
\hline & $(-4.52)$ & $(-1.41)$ & $(-4.34)$ & $(-4.31)$ \\
\hline \multirow[t]{2}{*}{ dREER } & 0.247 & -0.053 & 0.252 & 0.248 \\
\hline & $(0.52)$ & $(-0.08)$ & $(0.53)$ & $(0.52)$ \\
\hline \multirow[t]{2}{*}{ CEEC } & 0.029 & $0.801^{* * *}$ & $0.774^{\star * \star}$ & 0.288 \\
\hline & $(0.33)$ & $(8.38)$ & $(8.56)$ & $(3.11)$ \\
\hline \multirow[t]{2}{*}{ TUR dummy } & $0.712^{* * *}$ & & $0.378^{\star * *}$ & $0.528^{\star * *}$ \\
\hline & $(7.73)$ & & $(3.70)$ & $(5.08)$ \\
\hline \multicolumn{5}{|c|}{ DEVIATIONS FROM NORTH } \\
\hline \multirow[t]{2}{*}{ south1 } & & & -0.023 & \\
\hline & & & $(-0.30)$ & \\
\hline \multirow[t]{2}{*}{ south2 } & & & & -0.035 \\
\hline & & & & $(-0.49)$ \\
\hline$\overline{\text { R square }}$ & $\overline{0.80}$ & 0.58 & 0.80 & 0.80 \\
\hline F test model & 40.61 & 11.62 & 38.01 & 38.06 \\
\hline F test country & 117.06 & 58.31 & 94.73 & 93.05 \\
\hline F test time & 73.50 & 9.75 & 7.80 & 7.80 \\
\hline Hausman FE & 58 & 20.25 & 58.49 & 82.98 \\
\hline obs & 203 & 98 & 203 & 203 \\
\hline
\end{tabular}




\section{CESifo Working Paper Series}

(for full list see www.cesifo-group.de)

1485 Carsten Hefeker, Uncertainty, Wage Setting and Decision Making in a Monetary Union, June 2005

1486 Ondřej Schneider and Jan Zápal, Fiscal Policy in New EU Member States - Go East, Prudent Man!, June 2005

1487 Christian Schultz, Virtual Capacity and Competition, June 2005

1488 Yvan Lengwiler and Elmar Wolfstetter, Bid Rigging - An Analysis of Corruption in Auctions, June 2005

1489 Johannes Becker and Clemens Fuest, Does Germany Collect Revenue from Taxing Capital Income?, June 2005

1490 Axel Dreher and Panu Poutvaara, Student Flows and Migration: An Empirical Analysis, June 2005

1491 Bernd Huber and Marco Runkel, Interregional Redistribution and Budget Institutions under Asymmetric Information, June 2005

1492 Guido Tabellini, Culture and Institutions: Economic Development in the Regions of Europe, July 2005

1493 Kurt R. Brekke and Michael Kuhn, Direct to Consumer Advertising in Pharmaceutical Markets, July 2005

1494 Martín Gonzalez-Eiras and Dirk Niepelt, Sustaining Social Security, July 2005

1495 Alfons J. Weichenrieder, (Why) Do we need Corporate Taxation?, July 2005

1496 Paolo M. Panteghini, S-Based Taxation under Default Risk, July 2005

1497 Panos Hatzipanayotou and Michael S. Michael, Migration, Tied Foreign Aid and the Welfare State, July 2005

1498 Agata Antkiewicz and John Whalley, BRICSAM and the Non-WTO, July 2005

1499 Petr Hedbávný, Ondřej Schneider and Jan Zápal, A Fiscal Rule that has Teeth: A Suggestion for a 'Fiscal Sustainability Council' underpinned by the Financial Markets, July 2005

1500 J. Atsu Amegashie and Marco Runkel, Sabotaging Potential Rivals, July 2005 
1501 Heikki Oksanen, Actuarial Neutrality across Generations Applied to Public Pensions under Population Ageing: Effects on Government Finances and National Saving, July 2005

1502 Xenia Matschke, Costly Revenue-Raising and the Case for Favoring Import-Competing Industries, July 2005

1503 Horst Raff and Nicolas Schmitt, Why Parallel Trade may Raise Producers Profits, July 2005

1504 Alberto Bisin and Piero Gottardi, Efficient Competitive Equilibria with Adverse Selection, July 2005

1505 Peter A. Zadrozny, Necessary and Sufficient Restrictions for Existence of a Unique Fourth Moment of a Univariate GARCH(p,q) Process, July 2005

1506 Rainer Niemann and Corinna Treisch, Group Taxation, Asymmetric Taxation and Cross-Border Investment Incentives in Austria, July 2005

1507 Thomas Christiaans, Thomas Eichner and Ruediger Pethig, Optimal Pest Control in Agriculture, July 2005

1508 Biswa N. Bhattacharyay and Prabir De, Promotion of Trade and Investments between China and India: The Case of Southwest China and East and Northeast India, July 2005

1509 Jean Hindriks and Ben Lockwood, Decentralization and Electoral Accountability: Incentives, Separation, and Voter Welfare, July 2005

1510 Michelle R. Garfinkel, Stergios Skaperdas and Constantinos Syropoulos, Globalization and Domestic Conflict, July 2005

1511 Jesús Crespo-Cuaresma, Balázs Égert and Ronald MacDonald, Non-Linear Exchange Rate Dynamics in Target Zones: A Bumpy Road towards a Honeymoon - Some Evidence from the ERM, ERM2 and Selected New EU Member States, July 2005

1512 David S. Evans and Michael Salinger, Curing Sinus Headaches and Tying Law: An Empirical Analysis of Bundling Decongestants and Pain Relievers, August 2005

1513 Christian Keuschnigg and Martin D. Dietz, A Growth Oriented Dual Income Tax, July 2005

1514 Fahad Khalil, David Martimort and Bruno Parigi, Monitoring a Common Agent: Implications for Financial Contracting, August 2005

1515 Volker Grossmann and Panu Poutvaara, Pareto-Improving Bequest Taxation, August 2005

1516 Lars P. Feld and Emmanuelle Reulier, Strategic Tax Competition in Switzerland: Evidence from a Panel of the Swiss Cantons, August 2005 
1517 Kira Boerner and Silke Uebelmesser, Migration and the Welfare State: The Economic Power of the Non-Voter?, August 2005

1518 Gabriela Schütz, Heinrich W. Ursprung and Ludger Wößmann, Education Policy and Equality of Opportunity, August 2005

1519 David S. Evans and Michael A. Salinger, Curing Sinus Headaches and Tying Law: An Empirical Analysis of Bundling Decongestants and Pain Relievers, August 2005

1520 Michel Beine, Paul De Grauwe and Marianna Grimaldi, The Impact of FX Central Bank Intervention in a Noise Trading Framework, August 2005

1521 Volker Meier and Matthias Wrede, Pension, Fertility, and Education, August 2005

1522 Saku Aura and Thomas Davidoff, Optimal Commodity Taxation when Land and Structures must be Taxed at the Same Rate, August 2005

1523 Andreas Haufler and Søren Bo Nielsen, Merger Policy to Promote 'Global Players'? A Simple Model, August 2005

1524 Frederick van der Ploeg, The Making of Cultural Policy: A European Perspective, August 2005

1525 Alexander Kemnitz, Can Immigrant Employment Alleviate the Demographic Burden? The Role of Union Centralization, August 2005

1526 Baoline Chen and Peter A. Zadrozny, Estimated U.S. Manufacturing Production Capital and Technology Based on an Estimated Dynamic Economic Model, August 2005

1527 Marcel Gérard, Multijurisdictional Firms and Governments' Strategies under Alternative Tax Designs, August 2005

1528 Joerg Breitscheidel and Hans Gersbach, Self-Financing Environmental Mechanisms, August 2005

1529 Giorgio Fazio, Ronald MacDonald and Jacques Mélitz, Trade Costs, Trade Balances and Current Accounts: An Application of Gravity to Multilateral Trade, August 2005

1530 Thomas Christiaans, Thomas Eichner and Ruediger Pethig, A Micro-Level 'Consumer Approach' to Species Population Dynamics, August 2005

1531 Samuel Hanson, M. Hashem Pesaran and Til Schuermann, Firm Heterogeneity and Credit Risk Diversification, August 2005

1532 Mark Mink and Jakob de Haan, Has the Stability and Growth Pact Impeded Political Budget Cycles in the European Union?, September 2005

1533 Roberta Colavecchio, Declan Curran and Michael Funke, Drifting Together or Falling Apart? The Empirics of Regional Economic Growth in Post-Unification Germany, September 2005 
1534 Kai A. Konrad and Stergios Skaperdas, Succession Rules and Leadership Rents, September 2005

1535 Robert Dur and Amihai Glazer, The Desire for Impact, September 2005

1536 Wolfgang Buchholz and Wolfgang Peters, Justifying the Lindahl Solution as an Outcome of Fair Cooperation, September 2005

1537 Pieter A. Gautier, Coen N. Teulings and Aico van Vuuren, On-the-Job Search and Sorting, September 2005

1538 Leif Danziger, Output Effects of Inflation with Fixed Price- and Quantity-Adjustment Costs, September 2005

1539 Gerhard Glomm, Juergen Jung, Changmin Lee and Chung Tran, Public Pensions and Capital Accumulation: The Case of Brazil, September 2005

1540 Yvonne Adema, Lex Meijdam and Harrie A. A. Verbon, The International Spillover Effects of Pension Reform, September 2005

1541 Richard Disney, Household Saving Rates and the Design of Social Security Programmes: Evidence from a Country Panel, September 2005

1542 David Dorn and Alfonso Sousa-Poza, Early Retirement: Free Choice or Forced Decision?, September 2005

1543 Clara Graziano and Annalisa Luporini, Ownership Concentration, Monitoring and Optimal Board Structure, September 2005

1544 Panu Poutvaara, Social Security Incentives, Human Capital Investment and Mobility of Labor, September 2005

1545 Kjell Erik Lommerud, Frode Meland and Odd Rune Straume, Can Deunionization Lead to International Outsourcing?, September 2005

1546 Robert Inklaar, Richard Jong-A-Pin and Jakob de Haan, Trade and Business Cycle Synchronization in OECD Countries: A Re-examination, September 2005

1547 Randall K. Filer and Marjorie Honig, Endogenous Pensions and Retirement Behavior, September 2005

1548 M. Hashem Pesaran, Til Schuermann and Bjoern-Jakob Treutler, Global Business Cycles and Credit Risk, September 2005

1549 Ruediger Pethig, Nonlinear Production, Abatement, Pollution and Materials Balance Reconsidered, September 2005

1550 Antonis Adam and Thomas Moutos, Turkish Delight for Some, Cold Turkey for Others?: The Effects of the EU-Turkey Customs Union, September 2005 